\title{
Habitational abiotic environmental factors alter Arbuscular mycorrhizal composition, species richness and diversity index in Abroma augusta L. (Malvaceae) rhizosphere
}

\section{Parkash $\mathrm{V}^{1}$ and Saikia $\mathbf{A J}^{\mathbf{2}}$}

Mycology and Soil Microbiology Research and Technology Laboratory, Rain Forest Research Institute (Indian Council Forestry Research and Education, Autonomous Council under Ministry of Environment and Forests, Government of India), Deovan, Jorhat-785001, Assam, India. Email: 1 bhardwajvpnpark@ rediffmail.com; 2ankurj.saikia05@gmail.com

Parkash V, Saikia AJ 2015 - Habitational abiotic environmental factors alter Arbuscular mycorrhizal composition, species richness and diversity index in Abroma augusta L. (Malvaceae) rhizosphere. Plant Pathology \& Quarantine 5(2), 98-120, Doi 10.5943/ppq/5/2/8

\begin{abstract}
The scarce occurrence along with over-exploitation of Abroma augusta vis-à-vis its usage by practitioners of traditional medicinal system has augmented its importance among researchers and conservation biologists. The present study was an attempt to examine the alterations induced by abiotic environmental (i.e. climatic, biotic and physiographic) factors related to the plant habitat on the Arbuscular Mycorrhizal (AM) fungal partners of the target plant. Rhizospheric soils collected from 24 study sites of eight natural locations under six habitats from the Brahmaputra valley, Assam, India were assessed for AM populations. Through this study, a total of 22 AM fungal species under three genera (i.e. Glomus, Gigaspora and Acaulospora) were isolated. Riverine habitat augments AM spore density $(155 \pm 1.19)$ while fallows are characterized by maximum colonization by hyphae $(80 \pm 0.45)$ and arbuscules $(10 \pm 0.18)$. It is evident that increase in soil temperature and electrical conductivity, exhibited declining effect on the percent root colonization, AM spore numbers per $50 \mathrm{~g}$ of soil as well as AM ecological indices. The association between rhizospheric fungal biota including endomycorrhizae and abiotic soil properties can be exclusively advocated for a broader utilization as an ecological indicator for the conservation of target plant species which is discussed in this research paper.
\end{abstract}

Keywords - Abiotic influence - Ecological indices - Rhizospheric mycobiota - Soil physicochemical properties

\section{Introduction}

Soil is a structured, heterogeneous and discontinuous system, generally poor in nutrients and energy sources (in comparison with the concentrations optimal for nutrient microbial growth in vitro), with microorganisms living in discrete microhabitats (Stotzky 1997, Nannipieri et al. 2003). Variations in topography, climate, physical weathering processes, vegetation cover, microbial activities apart from several other biotic and abiotic variables, in the long run tend to differ physico-chemical characteristics of different soils with variance in space and time (Paudel \& Sah 2003). In other words, the quality of soil is not only related with physical and chemical properties, microbiological processes do also owe their share (Parkash et al. 2014). 
Arbuscular Mycorrhizal (AM) symbiosis is known to bring a wide range of benefits to the host plant in both agricultural production systems and natural ecosystems (Tanwar et al. 2014) by improving mineral uptake which leads to production of plants which perform better in terms of growth indices and environmental stress combat (Barea et al. 1993). Arbuscular Mycorrhizal fungi, characterized by "arbuscules" and "vesicles" formed by the aseptate, obligately symbiotic fungi of the phylum Glomeromycota (Schüßler et al. 2001) are an important asexually reproducing soil microbial community that forms symbiotic relationship with nearly 90 percent of the flowering plants (Brundrett 1991, Saikia \& Parkash 2014). Usually, plant, soil and climatic factors are related to the development of these fungi, and show varied effects on establishment of the mycorrhizal symbiosis and its efficiency (Carrenho et al. 2007). Certain edaphic characteristics have noteworthy influences on the development of AM fungi in roots, in an advantageous way such as potassium (K), nitrogen (Treseder 2004), $p \mathrm{H}$ (Isobe et al. 2007) and compaction (Waltert et al. 2002) apart from climatic conditions and host plant effects (Kivlin et al. 2011) as well as detrimental factors (e.g. Electrical conductivity, Available Phosphorus, etc.) (Isobe et al. 2007). So keeping in mind all these biological and chemical processes, the study was undertaken on Abroma augusta L. which is an important threatened plant species in Brahmaputra valley of Assam, India.

Abroma augusta is a popular plant belonging to family Malvaceae (previously under family Sterculiaceae) mainly used for the treatment of various types of disorder in the traditional systems of medicine (Patel \& Dhanabal 2013, Parkash et al. 2014). Owing to this medicament utility, the plant has been overexploited, which has consequently led to a decrease in its spread in forest areas, thereby limiting it to the forest edges; which showcases the urgent need to conserve this plant species, both in in situ as well as ex situ conditions (Parkash et al. 2013). Morphotaxonomically, it is evergreen plant with spreading branches, quick-growing pubescent shrub or a small tree with velvety branches, found in tropical Asia, South and eastern Africa and Australia (Das et al. 2012). It is found in both wild and cultivated areas, throughout the warm and moister parts of the Indian sub-continent ranging from Punjab and Uttar Pradesh eastwards to Arunachal Pradesh, Assam, Meghalaya and Tripura, ascending to $1,200 \mathrm{~m}$, and southwards in peninsular India (Anonymous 2006, Gupta et al. 2011).

The plant parts have been reported to contain several types of alkaloids and secondary metabolites inclusive of steroids, triterpenes, flavonoids, mega-stigmanes, benzo-hydrofurans and their glycosides and phenyl-ethanoid glycosides (Gupta et al. 2011, Saikot et al. 2012). The leaves of A. augusta contain octacosanol, taraxerol, B-sitosterol acetate, lupeol, an aliphatic alcohol $\left(\mathrm{C}_{32} \mathrm{H}_{66} \mathrm{O}\right)$ apart from mixture of long chain fatty diols. Abromine, the active constituent of the $A$. augusta identified as betaine is mainly responsible for anti-hyperglycemic activity (Mir et al. 2013). Certain diseases like diabetes, stomachache, dermatitis, leucorrhoea, scabies, gonorrhea, cough, leucoderma, jaundice, nerve stimulant, weakness, hypertension, uterine disorders, rheumatic pain of joints and headache with sinusitis have been treated with different parts of this plant (Rahmatullah et al. 2010). Moreover, its anti-dermatitic, anti- inflammatory as well as analgesic activity has also been reported (Al-Bari et al. 2006). Some preliminary studies have reported anti-diabetic activity of the dried root bark (aqueous extract) of A. augusta diabetic rats (Ali Hussain 2002, Eshrat 2003). Nahar et al. (2010) reported that the methanolic extract of leaves of $A$. augusta significantly reduced the blood glucose level in alloxan-induced diabetic rats when administered at a dose of $300 \mathrm{mg} / \mathrm{kg} / \mathrm{da}$. The root extracts of A. augusta might be a potential source of anti-diabetic agent for the treatment of Type-II diabetes and its $\alpha$-d-glucosidase inhibitory potential could be one of the possible mechanism for its anti-diabetic effect (Bisht et al. 2014). The fresh viscid sap of the root bark has been considered to be a valuable emmenagogue in addition to its usage as uterine tonic. It is also used in dysmenorrhoea (Kirtikar \& Basu 1918). This important plant species is nearing to its threshold due to overexploitation and needs conservation, particularly in Brahmaputra valley of Assam, India. Therefore, in this study an effort was made to analyze the relationship of AM fungal species with the rhizospheric physico-chemical properties so that both can be exploited for its conservation as a future strategy of this study. 


\section{Materials \& Methods}

\section{Survey and collection of seed and rhizospheric soil samples}

Owing to the scattered distribution of A. augusta, an extensive survey of different locations in Assam (India) was done for the collection of roots along with rhizospheric soil samples. Rhizospheric soil and roots were collected from 24 sampling sites under 8 natural locations/provenances of Brahmaputra valley, viz. Titabor, Borholla, Namrup, Nagamati, Kokilamukh, Kaziranga, Amsoi and Jagiroad where A. augusta was naturally occurring in these geographic locations and distributed in 4 districts i.e. Jorhat, Dibrugarh, Golaghat and Nagaon of Assam state in India (latitude $24^{\circ} 8^{\prime}$ to $24^{\circ} 2^{\prime} \mathrm{N}$ and longitude $89^{\circ} 42^{\prime}$ to $96^{\circ} 0^{\prime} \mathrm{E}$ ). These sites were also observed for their habitats as well as geo-positioning and/ or locational data. The majority of rain fall $(1800 \mathrm{~mm}$ to $3000 \mathrm{~mm})$ in these regions occur during monsoon period, i.e. March through May, the heaviest precipitation comes with the southwest monsoon, which arrives in June, stays through September, and often causes widespread and destructive flooding (Das 2014). The plant specimen were also collected, preserved in herbarium sheets for identification and deposited at herbarium of Rain Forest Research Institute, Jorhat, Assam. Rhizospheric soil samples (at least three samples) were taken by digging out a small amount of soil $(500 \mathrm{~g})$ close to plant roots up to the depth of $15-30 \mathrm{~cm}$ and these samples were kept in sterilized polythene bags at $10^{\circ} \mathrm{C}$ for further processing in the laboratory and physico-chemical analyses of soil.

\section{Physico-chemical analysis of soil}

The $p \mathrm{H}$ and soil temperature were measured for all soil samples using electronic digital $p \mathrm{H}$ meter (Eutech Instruments, Singapore) and soil thermometer (Jainco, India). Moisture content was determined by oven dry technique (Allen 1974). Organic carbon (\%) estimation was done by Walkley-Black's method (Walkley \& Black 1934). Colour of collected rhizospheric soil samples were given according to Munsell Soil Colour Code (Munsell 2000).

\section{Isolation and identification of rhizospheric AM Myco-biota}

Isolation, quantification and root colonization of VAM spores were done by using wet sieving and decanting technique (Gerdemann \& Nicolson 1963). The quantitative estimation of VAM spores was done by modified method of Adholeya \& Gaur (1994). To study the colonization of Arbuscular Mycorrhizae, the rapid clearing and staining method was employed (Phillips \& Hayman 1970). The AM fungi were identified using the keys of Trappe (1982), Walker (1992), Schenck \& Perez (1990), Morton \& Benny (1990), Mukerji (1996), Morton \& Redecker (2001) and Sharma et al. (2008, 2009). They were also identified by using websites (Blaszkowski 2003, Morton 2014). The AM fungal isolates with their accession numbers are preserved, trapped on host plants and retained with Mycology and Soil Microbiology Research Laboratory, Rain Forest Research Institute, Jorhat, Assam, India.

\section{Statistical analysis}

All the data were analyzed statistically, Analysis of the diversity parameters with respect to Arbuscular Mycorrhizal flora viz.-quantitative analysis such as density, frequency and abundance of rhizospheric soil myco-flora and diversity indices were computed based on standard methods and protocols (Curtis \& McIntosh 1950, Miller et al. 1987, Parkash 2012). Pearson's coefficient of correlation was calculated to study the relationship between different variables. For the statistical analyses, MS Excel 2007 was used.

\section{Results}

The physico-chemical data on $p \mathrm{H}$, moisture content, soil temperature, electrical conductivity, humidity and organic carbon of all the locations where A. augusta was naturally found to occur have been discussed in our previous research work (Parkash et al. 2014) where the 
diversity and distribution of rhizospheric non-mycorrhizal myco-biota associated with the target plant species was assessed. The said table in a more elaborative form has been presented in Table

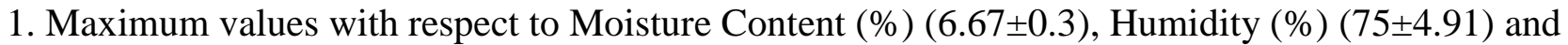
Soil Temperature $\left({ }^{\circ} \mathrm{C}\right)(34 \pm 0)$ were exhibited by the study site Borholla (study location BRHL/DHN/4); while the study site Kaziranga (study location KJRG/LJR/14) exhibited maximum values of plant height $(\mathrm{m})(8 \pm 0)$ and Available Soil Organic Carbon (\%) (1.5 \pm 0$)$. Although the Elevation (metres above sea level/masl) (130 \pm 0 masl) of study site Namrup (study location JPR/NMRP/5) was high; yet it presented low values of Moisture Content (\%) (3.47 \pm 0.21$)$

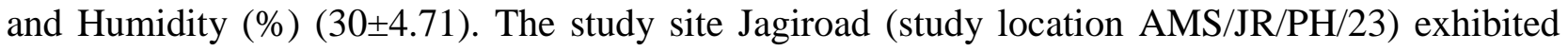
maximum value of Soil $p \mathrm{H}(8.4 \pm 0.28)$ and minimum value of Elevation (masl) $(56 \pm 0)$. With respect to Soil Electrical Conductivity $\left(\mathrm{dSm}^{-1}\right)$, highest $(125.1 \pm 7.07)$ value was exhibited by study site Borholla (study location BRHL/DDR/3) and lowest (40.3 \pm 2.36$)$ value was shown by study site Nagamati (study location JHPR/NGMT/8). On the other hand, minimum values with respect to Available Soil Organic Carbon $(\%)(0.06 \pm 0)$ and Soil $p \mathrm{H}(4.37 \pm 0.24)$ were exhibited by study site Titabor (study site TTBR/GPR/1); to plant height $(\mathrm{m})$ by study site Nagamati (study location JHPR/NGMT/10) as well as to Soil temperature $\left({ }^{\circ} \mathrm{C}\right)$ by study site Kokilamukh (study location KKLM/SAM/11), study site Kaziranga (study location KJRG/SJR/13 and KJRG/LJR/14) and study site Jagiroad (study location AMS/JR/PH/22) (20 \pm 0 ). Out of the various study locations, maximum sites were characterised by dull orange colour (5YR 6/3) (7 study locations), followed by Dull reddish brown (7.5R 5/3), Grayish brown (7.5YR 5/2), Brownish gray (7.5YR 6/1) (3, each), Light reddish gray (10R 7/1), Light brown gray (10YR 6/1) (2, each), Light olive gray (2.5GY 7/1), Dull brown (2.5YR 4/3), Dull reddish gray (5R 6/1), Brownish gray (7.5YR 4/1) (1, each).

Location/ Study site wise variation in endomycorrhizal quantification and spore density is discussed below (see Table 2). Maximum (155 $\pm 1.19 / 50 \mathrm{~g}$ soil) spore quantification was observed in Kokilamukh, while minimum (52 $\pm 0.94 / 50 \mathrm{~g}$ soil) spore density was observed in the study location Titabor. Maximal percentage of hyphal colonization $(80 \pm 0.53)$ and vesicular infection $(30 \pm 0.07)$ was observed in the study site Nagamati. On the other hand, low rate of hyphal and

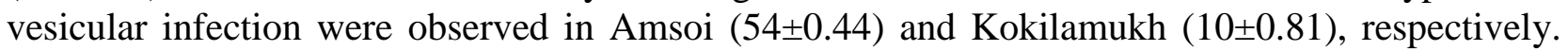
Noteworthy is the fact that no vesicular infection was observed among the samples (AMS/JR/PH/20, AMS/JR/PH/21, AMS/JR/PH/22, AMS/JR/PH/23 and AMS/JR/PH/24) collected from the site Jagiroad, while only one sample (AMS/JR/PH/22) from the mentioned site exhibited scanty $(10 \pm 0.18)$ arbuscular infection.

With reference to the study site habitat, analyses of the mentioned parameters divulge the following observations (see Tables 3, 4 and 5). The foot hill regions characterized by high plant height $(7.5 \mathrm{~m})$ and Soil Organic Carbon $(1.29 \%)$ and low $p \mathrm{H}(5.1)$, moisture content $(3.47 \%)$, electrical conductivity $\left(43.6 \mathrm{dSm}^{-1}\right)$ and humidity (30\%) exhibited high AM spore density (155/ $50 \mathrm{~g}$ of soil) and per cent vesicular infection (20). On the other hand, River side locations typified by high $p \mathrm{H}(8.2)$, electrical conductivity $\left(91.4 \mathrm{dSm}^{-1}\right)$ and relatively low $\left(20^{\circ} \mathrm{C}\right)$ soil temperature displayed lower percent vesicular infection (10). Only fallow land revealed scanty (10) percent arbuscular infection, the habitat being highly (5.28) humid and with comparatively lower $\left(20^{\circ} \mathrm{C}\right)$ soil temperature. The rest study habitats revealed mere absence of percent arbuscular infection. The parameters will be illustrated below with reference to elevation of the study locations (see Tables 1, 2 and Fig. 2). Maximum (155 $\pm 2.83 / 50 \mathrm{~g}$ of soil) spore density and hyphal colonization $(80 \pm 0.53)$ were observed at high elevation sites (130 and 118 masl's, respectively). However, lower values with respect to spore population $(42 \pm 0.47)$ and hyphal colonization 
Table 1 Physico-chemical properties of the collected soil samples of Abroma augusta

\begin{tabular}{|c|c|c|c|c|c|c|c|c|c|c|c|}
\hline $\begin{array}{l}\text { Sl. } \\
\text { No. }\end{array}$ & Sample numbers & Locations & $\begin{array}{l}\text { Height } \\
\text { of } \\
\text { plant } \\
\text { (m) }\end{array}$ & Soil $p H$ & $\begin{array}{l}\text { Soil Electrical } \\
\text { Conductivity } \\
\left(\mathbf{d S m}^{-1}\right)\end{array}$ & $\begin{array}{c}\text { Soil } \\
\text { Temp. } \\
\left({ }^{\circ} \mathrm{C}\right)\end{array}$ & $\begin{array}{c}\text { Soil } \\
\text { Organic } \\
\text { Carbon } \\
(\%)\end{array}$ & $\begin{array}{c}\text { Relative } \\
\text { Humidity } \\
(\%)\end{array}$ & $\begin{array}{c}\text { Site } \\
\text { Elevation } \\
(\mathbf{m})\end{array}$ & $\begin{array}{l}\text { Soil Moisture } \\
\text { Content }(\%)\end{array}$ & $\begin{array}{c}\text { Soil colour } \\
\text { (with Munsell Code) }\end{array}$ \\
\hline 1. & TTBR/GPR/1 & Titabor & $3.15 \pm 0$ & $4.37 \pm 0.24$ & $80.8 \pm 4.71$ & $33 \pm 0$ & $0.06 \pm 0$ & $55 \pm 2.36$ & $78 \pm 0$ & $4.44 \pm 0.11$ & $\begin{array}{l}\text { Dull orange } \\
(5 \text { YR } 6 / 3)\end{array}$ \\
\hline 2. & BRHL/MDP/2 & Borholla & $3 \pm 0$ & $5.74 \pm 0.26$ & $47.1 \pm 5.45$ & $32 \pm 0$ & $0.72 \pm 0$ & $65 \pm 3.21$ & $88 \pm 0$ & $5.84 \pm 0.25$ & $\begin{array}{l}\text { Light brown gray } \\
\text { (10YR 6/1) }\end{array}$ \\
\hline 3. & BRHL/DDR/3 & & $6 \pm 0$ & $4.54 \pm 0.47$ & $125.1 \pm 7.07$ & $33 \pm 0$ & $0.3 \pm 0$ & $67 \pm 4.24$ & $88 \pm 0$ & $5.5 \pm 0.24$ & $\begin{array}{l}\text { Dull orange } \\
(5 \mathrm{YR} 6 / 3)\end{array}$ \\
\hline 4. & BRHL/DHN/4 & & $4 \pm 0$ & $4.43 \pm 0.35$ & $109.4 \pm 4.95$ & $34 \pm 0$ & $0.42 \pm 0$ & $75 \pm 4.91$ & $75 \pm 0$ & $6.67 \pm 0.3$ & $\begin{array}{l}\text { Dull orange } \\
(5 \text { YR } 6 / 3)\end{array}$ \\
\hline 5. & JPR/NMRP/5 & Namrup & $7.5 \pm 0$ & $5.1 \pm 0.21$ & $43.6 \pm 9.43$ & $21 \pm 0$ & $1.29 \pm 0$ & $30 \pm 4.71$ & $130 \pm 0$ & $3.47 \pm 0.21$ & $\begin{array}{l}\text { Dull reddish brown } \\
(7.5 \mathrm{R} 5 / 3)\end{array}$ \\
\hline 6. & JPR/FCI/6 & & $5 \pm 0$ & $5.33 \pm 0.32$ & $81.3 \pm 2.83$ & $23 \pm 0$ & $0.99 \pm 0$ & $32 \pm 3.07$ & $117 \pm 0$ & $4.47 \pm 0.24$ & $\begin{array}{l}\text { Light reddish gray } \\
(10 \mathrm{R} 7 / 1)\end{array}$ \\
\hline 7. & JPR/PRBR/7 & & $4 \pm 0$ & $5.22 \pm 0.21$ & $41.3 \pm 4.38$ & $23 \pm 0$ & $1.35 \pm 0$ & $40 \pm 2.36$ & $117 \pm 0$ & $3.59 \pm 0.19$ & $\begin{array}{l}\text { Light reddish gray } \\
(10 \mathrm{R} 7 / 1)\end{array}$ \\
\hline 8. & JPR/NGMT/8 & Nagamati & $3 \pm 0$ & $6.54 \pm 0.34$ & $40.3 \pm 2.36$ & $23 \pm 0$ & $0.45 \pm 0$ & $45 \pm 3.3$ & $118 \pm 0$ & $3.81 \pm 0.14$ & $\begin{array}{l}\text { Brownish gray } \\
(7.5 \text { YR 6/1) }\end{array}$ \\
\hline 9. & JPR/NGMT/9 & & $2.8 \pm 0$ & $6.26 \pm 0.12$ & $48.4 \pm 4.78$ & $23 \pm 0$ & $0.36 \pm 0$ & $45 \pm 4.71$ & $118 \pm 0$ & $4.36 \pm 0.15$ & $\begin{array}{l}\text { Brownish gray } \\
\text { (7.5YR 6/1) }\end{array}$ \\
\hline 10. & JPR/NGMT/10 & & $2.5 \pm 0$ & $5.43 \pm 0.19$ & $41.5 \pm 2.24$ & $23 \pm 0$ & $0.3 \pm 0$ & $45 \pm 3.21$ & $118 \pm 0$ & $4.74 \pm 0.12$ & $\begin{array}{l}\text { Grayish brown } \\
(7.5 \mathrm{YR} 5 / 2)\end{array}$ \\
\hline 11. & KKLM/SAM/11 & Kokilamukh & $6 \pm 0$ & $8.2 \pm 0.24$ & $91.4 \pm 4.41$ & $20 \pm 0$ & $0.81 \pm 0$ & $50 \pm 2.4$ & $63 \pm 0$ & $4.6 \pm 0.28$ & $\begin{array}{l}\text { Light olive gray } \\
(2.5 \mathrm{GY} 7 / 1)\end{array}$ \\
\hline 12. & KJRG/NMGP/12 & Kaziranga & $3.5 \pm 0$ & $5.05 \pm 0.2$ & $74.6 \pm 1.89$ & $28 \pm 0$ & $0.99 \pm 0$ & $48 \pm 3.77$ & $65 \pm 0$ & $4.47 \pm 0.21$ & $\begin{array}{l}\text { Light brownish gray } \\
(10 \text { YR } 6 / 1)\end{array}$ \\
\hline 13. & KJRG/SJR/13 & & $6.5 \pm 0$ & $5.27 \pm 0.11$ & $57.6 \pm 3.44$ & $20 \pm 0$ & $0.96 \pm 0$ & $58 \pm 1.91$ & $57 \pm 0$ & $5.82 \pm 0.38$ & $\begin{array}{l}\text { Brownish gray } \\
(7.5 \text { YR 6/1) }\end{array}$ \\
\hline 14. & KJRG/LJR/14 & & $8 \pm 0$ & $5.43 \pm 0.2$ & $96.1 \pm 2.83$ & $20 \pm 0$ & $1.5 \pm 0$ & $55 \pm 1.41$ & $74 \pm 0$ & $4.72 \pm 0.17$ & $\begin{array}{l}\text { Grayish brown } \\
(7.5 \text { YR 5/2) }\end{array}$ \\
\hline 15. & AMS/ROM/15 & Amsoi & $3.5 \pm 0$ & $7.06 \pm 0.15$ & $65.4 \pm 2.36$ & $22 \pm 0$ & $0.63 \pm 0$ & $50 \pm 3.8$ & $73 \pm 0$ & $4.19 \pm 0.39$ & $\begin{array}{l}\text { Brownish gray } \\
\text { (7.5YR 4/1) }\end{array}$ \\
\hline 16. & AMS/ROM/16 & & $4.5 \pm 0$ & $7.3 \pm 0.14$ & $71.8 \pm 4.95$ & $22 \pm 0$ & $0.69 \pm 0$ & $38 \pm 4.75$ & $70 \pm 0$ & $3.53 \pm 0.22$ & $\begin{array}{l}\text { Dull reddish gray } \\
(5 \mathrm{R} 6 / 1)\end{array}$ \\
\hline
\end{tabular}


Table 1 continued

\begin{tabular}{|c|c|c|c|c|c|c|c|c|c|c|c|}
\hline $\begin{array}{l}\text { Sl. } \\
\text { No. }\end{array}$ & $\begin{array}{c}\text { Sample } \\
\text { numbers }\end{array}$ & Locations & $\begin{array}{l}\text { Height } \\
\text { of plant } \\
\text { (m) }\end{array}$ & Soil $p H$ & $\begin{array}{c}\text { Soil } \\
\text { Electrical } \\
\text { Conductivity } \\
\left(\mathbf{d S m}^{-1}\right)\end{array}$ & $\begin{array}{c}\text { Soil } \\
\text { Temp. } \\
\left({ }^{\circ} \mathrm{C}\right)\end{array}$ & $\begin{array}{c}\text { Soil } \\
\text { Organic } \\
\text { Carbon } \\
(\%)\end{array}$ & $\begin{array}{c}\text { Relative } \\
\text { Humidity } \\
(\%)\end{array}$ & $\begin{array}{c}\text { Site } \\
\text { Elevation } \\
\text { (m) }\end{array}$ & $\begin{array}{l}\text { Soil Moisture } \\
\text { Content }(\%)\end{array}$ & $\begin{array}{c}\text { Soil colour } \\
\text { (with Munsell Code) }\end{array}$ \\
\hline 17. & AMS/ROM/17 & & $5.5 \pm 0$ & $5.95 \pm 0.27$ & $104.2 \pm 3.57$ & $22 \pm 0$ & $0.3 \pm 0$ & $40 \pm 2.83$ & $68 \pm 0$ & $3.8 \pm 0.38$ & $\begin{array}{l}\text { Dull reddish brown } \\
(7.5 \mathrm{R} 5 / 3)\end{array}$ \\
\hline 18. & AMS/ROM/18 & Jagiroad & $3.5 \pm 0$ & $5.4 \pm 0.47$ & $53 \pm 2.16$ & $21 \pm 0$ & $0.21 \pm 0$ & $40 \pm 1.89$ & $66 \pm 0$ & $3.97 \pm 0.27$ & $\begin{array}{l}\text { Dull orange } \\
(5 \text { YR } 6 / 3)\end{array}$ \\
\hline 19. & AMS/ROM/19 & & $3.5 \pm 0$ & $7.7 \pm 0.19$ & $62 \pm 1.69$ & $22 \pm 0$ & $0.15 \pm 0$ & $40 \pm 3.6$ & $66 \pm 0$ & $4.02 \pm 0.26$ & $\begin{array}{l}\text { Dull orange } \\
\text { (5YR 6/3) }\end{array}$ \\
\hline 20. & AMS/JR/PH/20 & & $5.5 \pm 0$ & $5.62 \pm 0.14$ & $63.3 \pm 1.41$ & $22 \pm 0$ & $0.87 \pm 0$ & $45 \pm 4.48$ & $72 \pm 0$ & $3.96 \pm 0.18$ & $\begin{array}{l}\text { Dull orange } \\
(5 \text { YR } 6 / 3)\end{array}$ \\
\hline 21. & AMS/JR/PH/21 & Jagiroad & $6.5 \pm 0$ & $5.65 \pm 0.24$ & $63.9 \pm 2.36$ & $22 \pm 0$ & $1.29 \pm 0$ & $47 \pm 5.19$ & $70 \pm 0$ & $4.38 \pm 0.29$ & $\begin{array}{l}\text { Dull orange } \\
(5 \text { YR } 6 / 3)\end{array}$ \\
\hline 22. & AMS/JR/PH/22 & & $5.5 \pm 0$ & $5.69 \pm 0.38$ & $63.4 \pm 3.54$ & $20 \pm 0$ & $0.87 \pm 0$ & $50 \pm 3.31$ & $57 \pm 0$ & $5.28 \pm 0.47$ & $\begin{array}{l}\text { Dull reddish brown } \\
(7.5 R 5 / 3)\end{array}$ \\
\hline 23. & AMS/JR/PH/23 & & $5.5 \pm 0$ & $8.4 \pm 0.28$ & $91.4 \pm 2.88$ & $21 \pm 0$ & $0.99 \pm 0$ & $50 \pm 4.01$ & $56 \pm 0$ & $4.98 \pm 0.31$ & $\begin{array}{l}\text { Grayish brown } \\
(7.5 \text { YR 5/2) }\end{array}$ \\
\hline 24. & AMS/JR/PH/24 & & $7.5 \pm 0$ & $6.76 \pm 0.34$ & $87.5 \pm 4.18$ & $22 \pm 0$ & $0.57 \pm 0$ & $50 \pm 3.54$ & $57 \pm 0$ & $4.47 \pm 0.42$ & $\begin{array}{l}\text { Dull brown } \\
(2.5 \text { YR } 4 / 3)\end{array}$ \\
\hline
\end{tabular}

Mean of three replicates, $\pm=\mathrm{SEm}$ (Standard error of mean) 
Table 2 Status of endomycorrhizal (AM) quantification and root colonization of collected samples of Abroma augusta

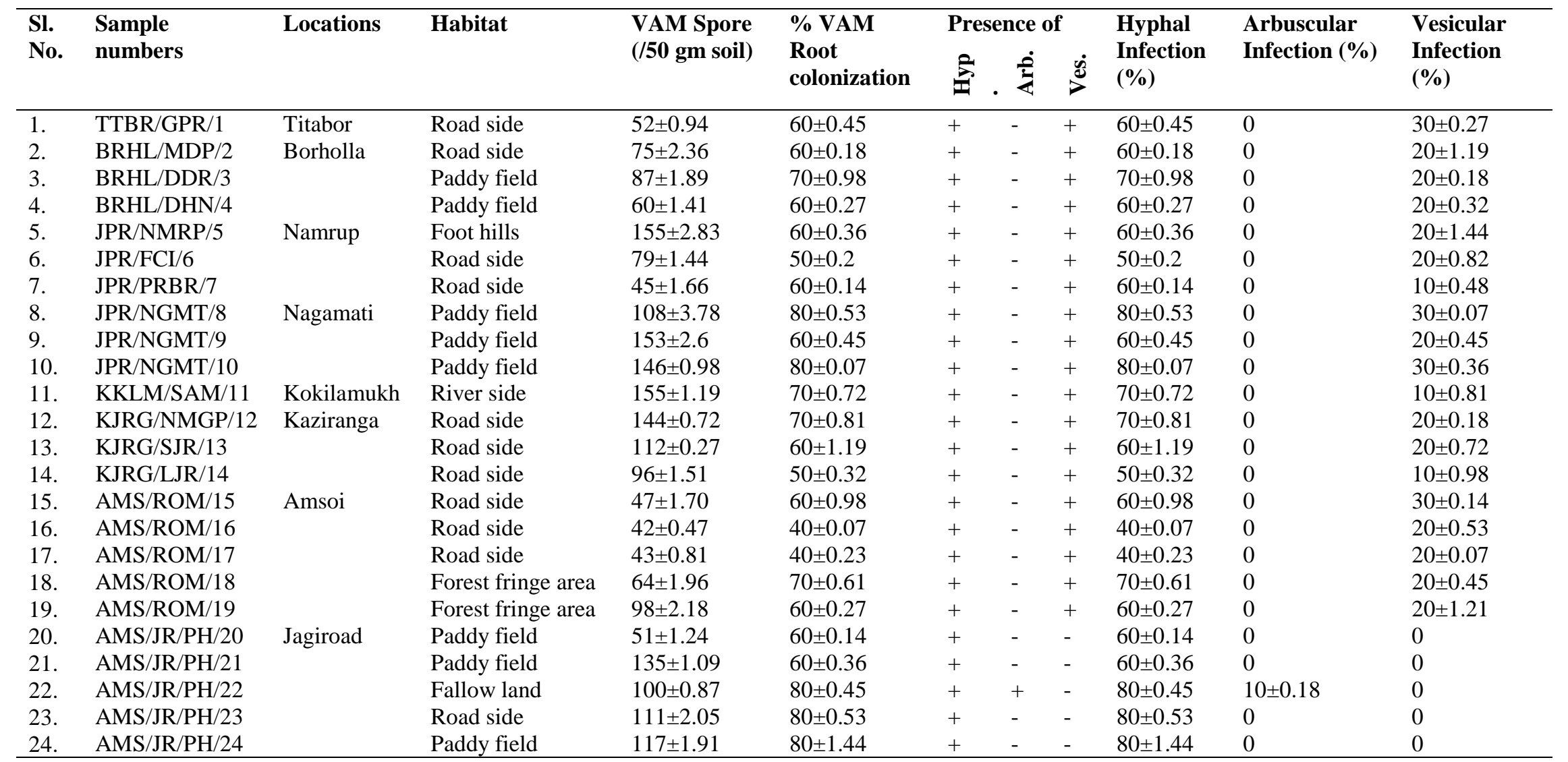

Mean of five replicates, $\pm=$ SEm (Standard error of mean); Hyp-Hyphae, Arb-Arbuscule, Ves-Vesicle 
Table 3 Habitat- and Location-wise natural occurrence and diversity of AM fungi in rhizosphere of Abroma augusta

\begin{tabular}{|c|c|c|c|c|c|c|c|c|c|c|c|c|c|c|c|}
\hline Total & 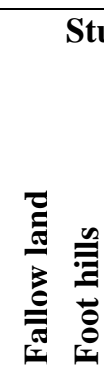 & 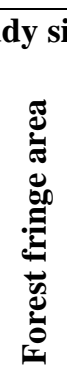 & 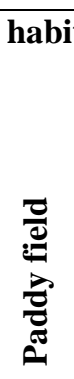 & 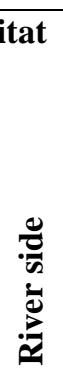 & 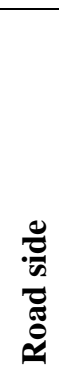 & $\begin{array}{l}\text { Name of endomycorrhizal (AM) fungal } \\
\text { species }\end{array}$ & 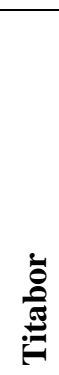 & 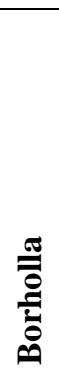 & 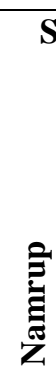 & 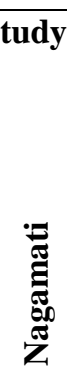 & 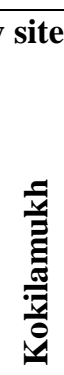 & 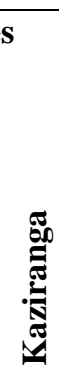 & 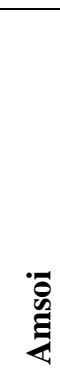 & 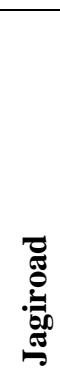 & Total \\
\hline 4 & & + & + & + & + & Acaulospora laevis Gerd. \& Trappe & & & & + & + & & + & & \\
\hline 4 & + & + & + & & + & A. foveata Trappe \& Janos & & & + & + & & & + & + & 4 \\
\hline 2 & & + & & & + & A. mellea Spain \& Schenk & & & & & & & + & & 1 \\
\hline 2 & & & + & & + & A. denticulata & + & + & + & + & & + & + & + & 7 \\
\hline 1 & & & + & & & A. bireticulata & & & & + & & & & & 1 \\
\hline 2 & & & + & & + & A. scrobiculata & & & & + & & & + & & 2 \\
\hline 2 & & & + & & + & A. sp. & & & + & & & & + & + & 3 \\
\hline 1 & & & + & & & Gigaspora gigantea & & + & & & & & & & 1 \\
\hline 2 & & & + & & + & Gi. sp. & + & & & + & & & & & 2 \\
\hline 1 & & & + & & & Glomus albidum & & & & + & & & & & 1 \\
\hline 4 & + & + & + & & + & $\begin{array}{l}\text { Gl. clavisporum (Trappe) Almeida \& } \\
\text { Schenck }\end{array}$ & & & + & & & + & + & + & 4 \\
\hline 4 & + & + & + & & + & Gl.geosporum & & & & & & + & + & + & 3 \\
\hline 1 & & & + & & & Gl. convulutum & & + & & & & & & & 1 \\
\hline 3 & + & & + & & + & Gl. macrocarpum & & + & + & & & & & & 2 \\
\hline 2 & & + & + & & & Gl.mosseae & & & & + & & & + & & 2 \\
\hline 1 & & & & & + & Gl. multicaulis & & & + & & & & & & 1 \\
\hline 1 & & & & & + & Gl. multisubstensum & & & & & & + & & & 1 \\
\hline 3 & & + & + & & + & Gl. pallidum Hall & + & + & & & & + & + & & 4 \\
\hline 1 & & & & & + & Gl.pansihalos & + & & & & & & & & 1 \\
\hline 1 & & & & & + & $G l$. sp. & & + & + & & & & & & 2 \\
\hline 1 & & & & & + & Gl. microcarpum Tulasne \& Tulasne & & & & & & & & + & 1 \\
\hline 1 & & & + & & & Gl.segmentatum & & & & & & & & + & 1 \\
\hline
\end{tabular}

$(40 \pm 0.07)$ were observed at a lower (70 masl) altitude. Mention worthy fact is that the scanty $(10 \pm 0.18)$ arbuscular infection was only observed at lowermost (57 masl) altitude. The percent vesicular infection showed a trend similar to spore density, with observance of maximum $(30 \pm 0.36)$ and minimum $(10 \pm 0.81)$ values at higher (118 masl) and lower (63 masl) values of altitudes.

With reference to AM generic diversity, the study revealed maximum dominance (13) of Glomus in the rhizosphere of A. augusta, followed by Acaulospora (7); while the least dominant genus was found to be Gigaspora (2) (see Table 7 and Figs 1,3,6). A total of 22 species of AM fungi belonging to 3 genera (i.e. Glomus, Gigaspora and Acaulospora) were isolated from the rhizospheric soil of A. augusta as illustrated in the above mentioned table and figures. The natural occurrence and density of AM fungi was observed highest $(37.5 \%, 1.13)$ in case of Acaulospora bireticulata Rothwell \& Trappe and lowest $(4.17 \%, 0.13)$ in A. denticulata Seiverding \&Toro; Gigaspora gigantea Gerd. \& Trappe; Glomus albidum Walker \& Rhodes; Gl. convolutum Gerd. \& Trappe; Gl. multicaulis Gerd. \& Bakshi; Gl. multisubstensum Mukerji, Bhattacharjee \& Tewari; Gl. pansihalos Bersch \& Koske; Gl. macrocarpum Tul. \& Tul. and Gl. segmentatum Trappe, Spooner \& Ivory; each respectively. The highest abundance value (2.33) was observed in $G l$. geosporum (Nicol. \& Gerd.) Walker and lowest value (1) in Acaulospora bireticulata, A. scrobiculata Trappe, Gi. gigantea, Gi. sp., Gl. albidum, Gl. clavisporum Almeida \& Schenck, Gl. convolutum, Gl. mosseae Gerd. \& Trappe, Gl. multicaulis, Gl. multisubstensum, Gl. pansihalos, Gl. sp., Gl. macrocarpum and Gl. segmentatum each respectively. The species-wise frequency was 
highest (87.5) for A. bireticulata and lowest (12.5) for A. denticulata, A. scrobiculata, Gi. gigantea, Gl. albidum, Gl. convolutum, Gl. multicaulis, Gl. multisubstensum, Gl. pansihalos, Gl. macrocarpum and $G l$. segmentatum. The region wise frequency was highest (37.5) for $A$. bireticulata and lowest (4.17) for A. scrobiculata, Gi. gigantea, Gl. albidum, Gl. convolutum, Gl. multicaulis, Gl. multisubstensum, Gl. pansihalos, Gl. macrocarpum and Gl. segmentatum.

Table 4 Elevation wise natural occurrence and diversity of AM fungi in the collected soil samples of Abroma augusta

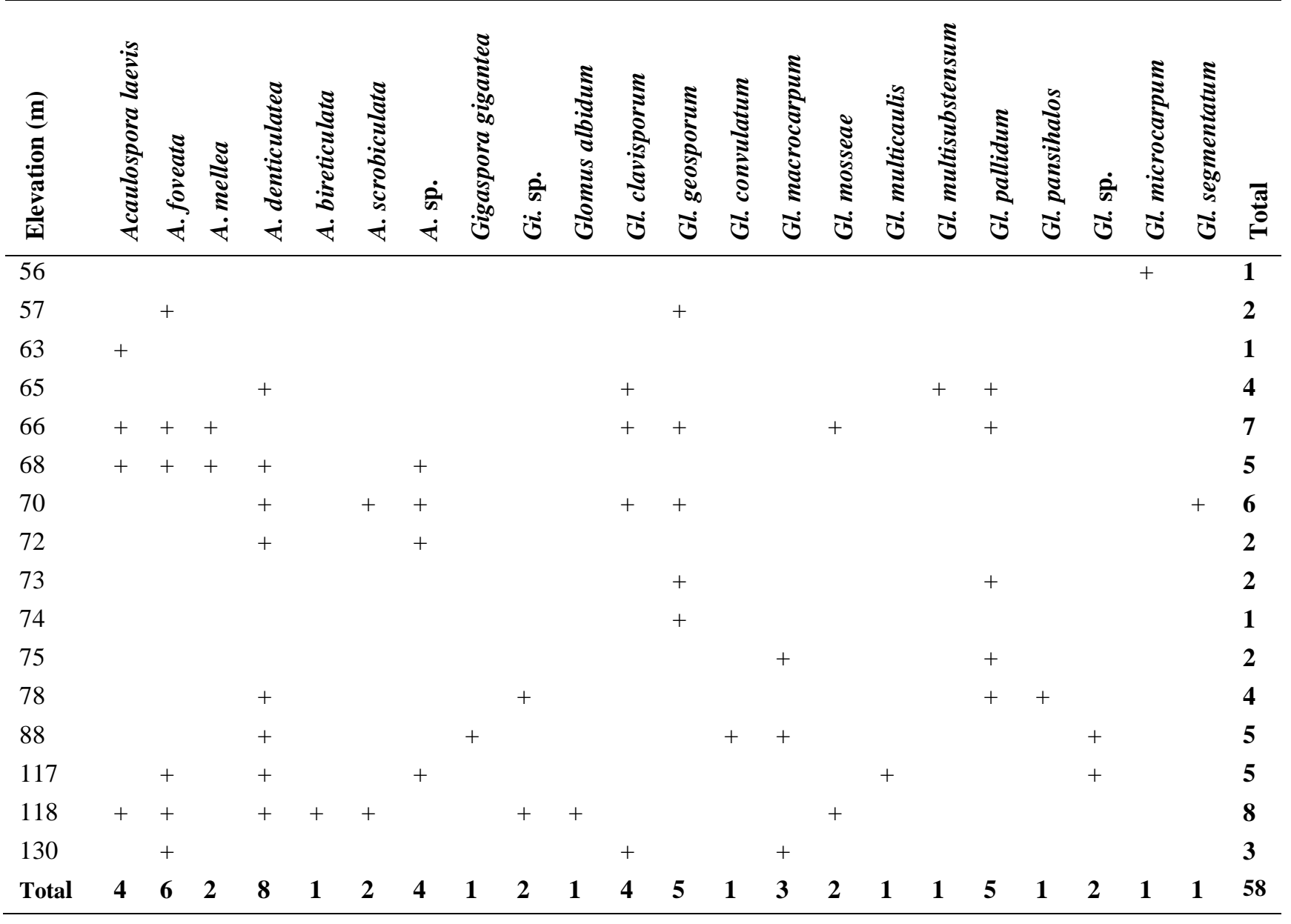

Maximum AM diversity with reference to study site, study location, habitat type and elevation were observed in JPR/NGMT/10 (6), Amsoi (10), Paddy field, Road side (16, each) and 118 masl elevation (8), respectively. On the other hand minimum values with respect to the above mentioned parameters were exhibited by JPR/FCI/6, KKLM/SAM/11, KJRG/SJR/13, KJRG/LJR/14, AMS/JR/PH/22, AMS/JR/PH/23 and AMS/JR/PH/24 (1, each); Kokilamukh (1); Fallow land (1); 56, 63 and 74 (1, each) (see Tables 3,4,5,6 and Figs 2,3,4).

The region-wise variation related to the species richness and diversity index is shown in Table 3. The study of species richness and diversity index showed that maximum species richness value (16.94) was observed in Amsoi; whereas minimum species richness (4.75) in Titabor location. Again the highest diversity index value was observed in Amsoi (0.06); while Borholla, Nagamati and Kaziranga had almost meager diversity index value (0.01). No species richness was observed at Kokilamukh; while diversity index was nil at Titabor and Kokilamukh study sites. 


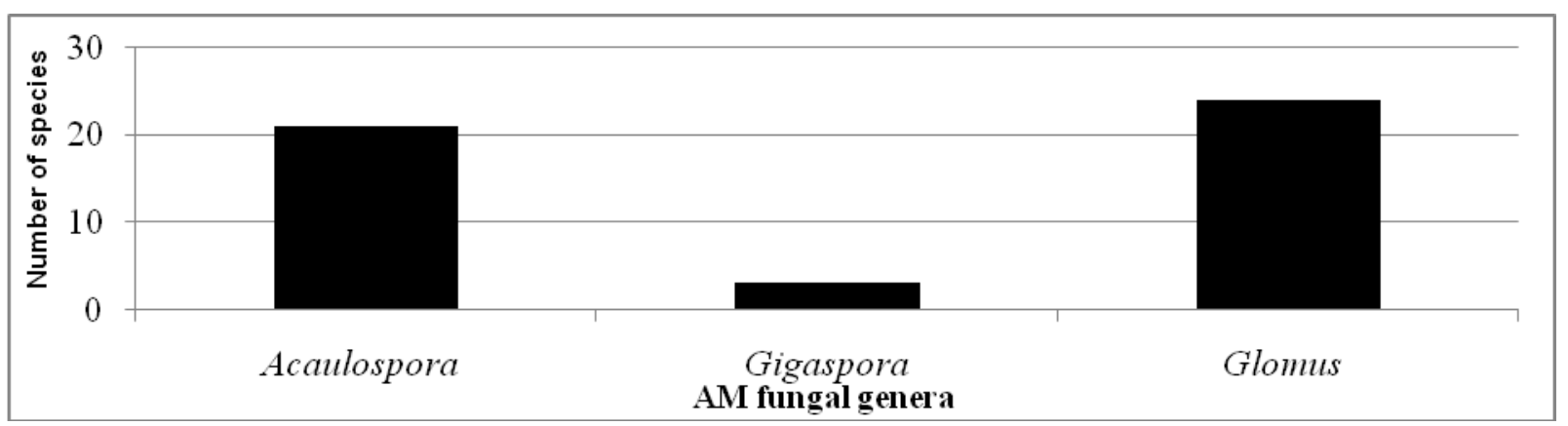

Fig. 1 - Distribution of Arbuscular Mycorrhizal species in rhizosphere (on an average data)

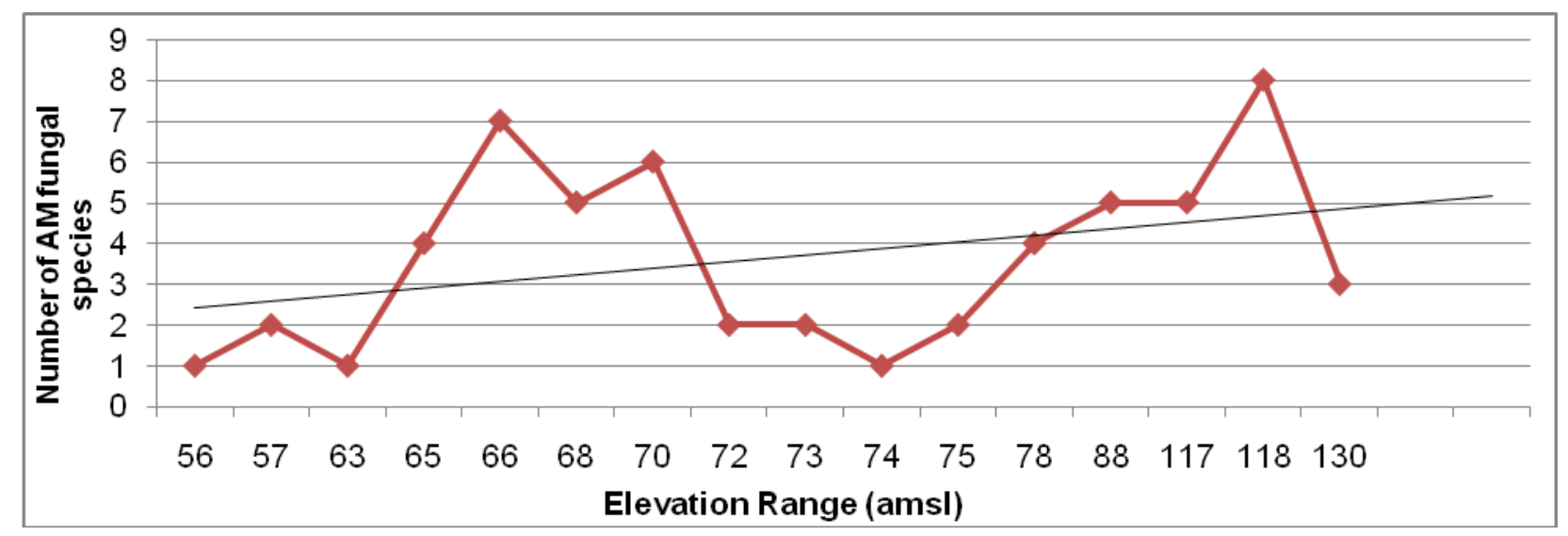

Fig. 2 - Elevation wise variation in Arbuscular Mycorrhizal species (based on an average data)

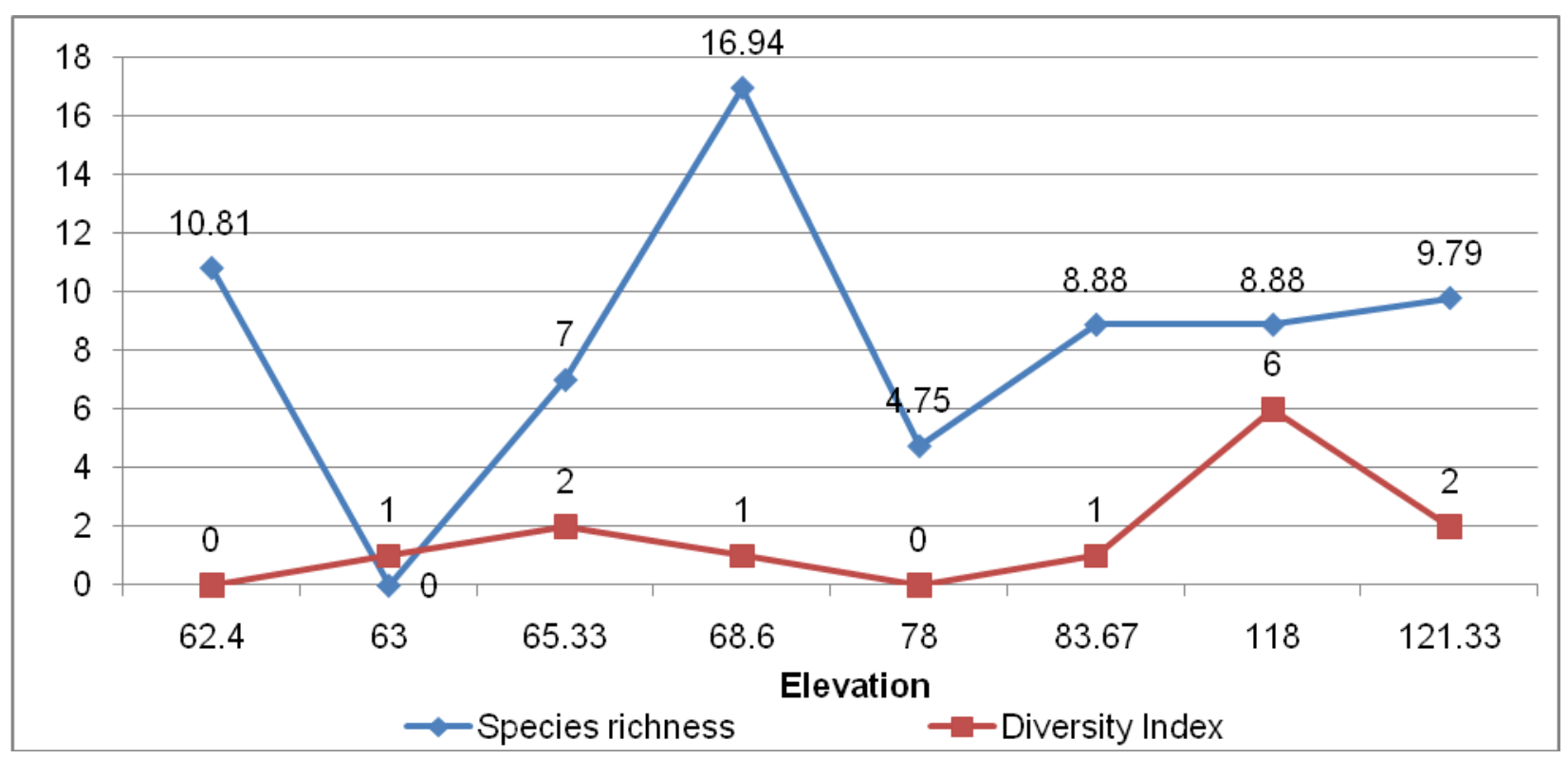

Fig. 3 - Elevation wise diversity index and species richness of AM fungi in rhizosphere of Abroma augusta

Categorization of elevation, a principal physico-chemical parameter into high (111 masl and above), medium (81-110 masl) and low (50-81 masl) ranges was done, upon which further analysis of endomycorrhizal quantification data and ecological indices was performed (Figs 2, 4). A gradual increase in AM fungal populace $(86.51<117.56)$ and percent vesicular infection 
$(14.72<20.56)$ was observed with a simultaneous increase in elevation $(50-80$ masl $<111$ masl and above). On the other hand, an inverse trend was observed in this study with regard to arbuscular infection $(0.28>0.00)$ in context of increment in elevation $(50-80$ masl $<111$ masl and above). Again, percent hyphal colonization remained almost the same with rise in elevation; while the parameter boosted to some extent on attaining the medium range.

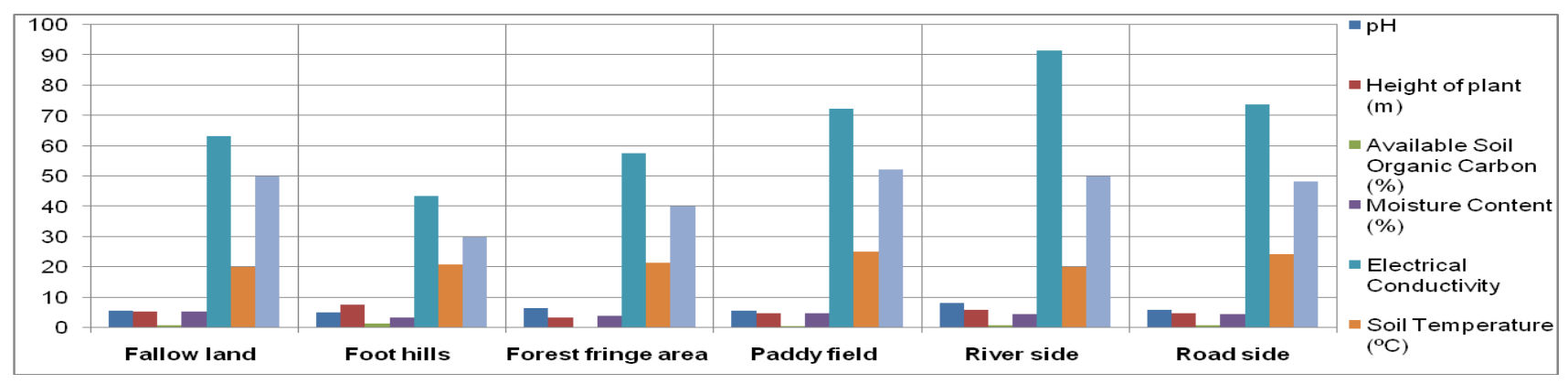

Fig. 4 - Habitat wise variation in edaphic and other environmental factors/ parameters (on an average data)

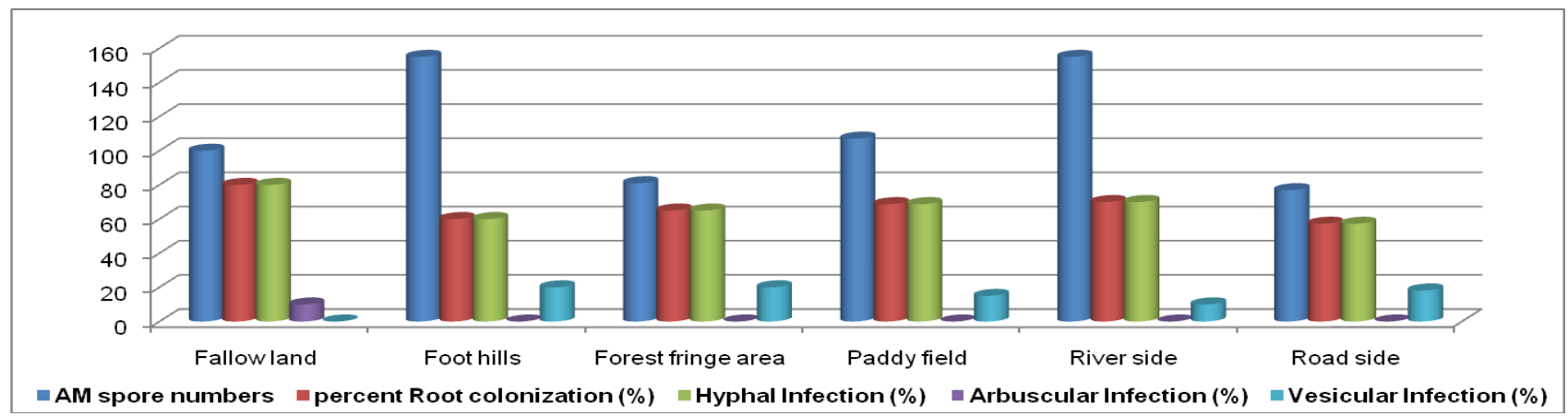

Fig. 5 - Habitat wise variation in endomycorrhizal quantification and root colonization (on an average data)

The inter-relationship ascertained on the basis of Pearson's correlation coefficient values for different external environmental factors (variables like Height of plant, Soil $p \mathrm{H}$, Soil Electrical Conductivity, Soil Temperature, Soil Moisture Content (\%), Available Soil Organic Carbon (\%), Relative Humidity and Site Elevation) versus endomycorrhizal (AM) quantification, root colonization of collected samples and ecological indices of study sites has been depicted in Table 8. percent Root colonization was positively $(0.14,0.23$ and 0.20$)$ correlated with Soil $p \mathrm{H}$, Soil Moisture Content (\%) as well as Relative Humidity. AM spore quantification was positively $(0.20$, 0.16, 0.06, 0.21 and 0.18) correlated with several environmental variables, viz.- plant height, Soil $p \mathrm{H}$, Soil Moisture Content (\%), Available Soil Organic Carbon (\%) and Site Elevation, respectively. With reference to the ecological indices, Species richness was correlated $(0.13)$ with site elevation; while Diversity index exhibited a slight level of concurrence $(0.18)$ with soil $p \mathrm{H}$. 


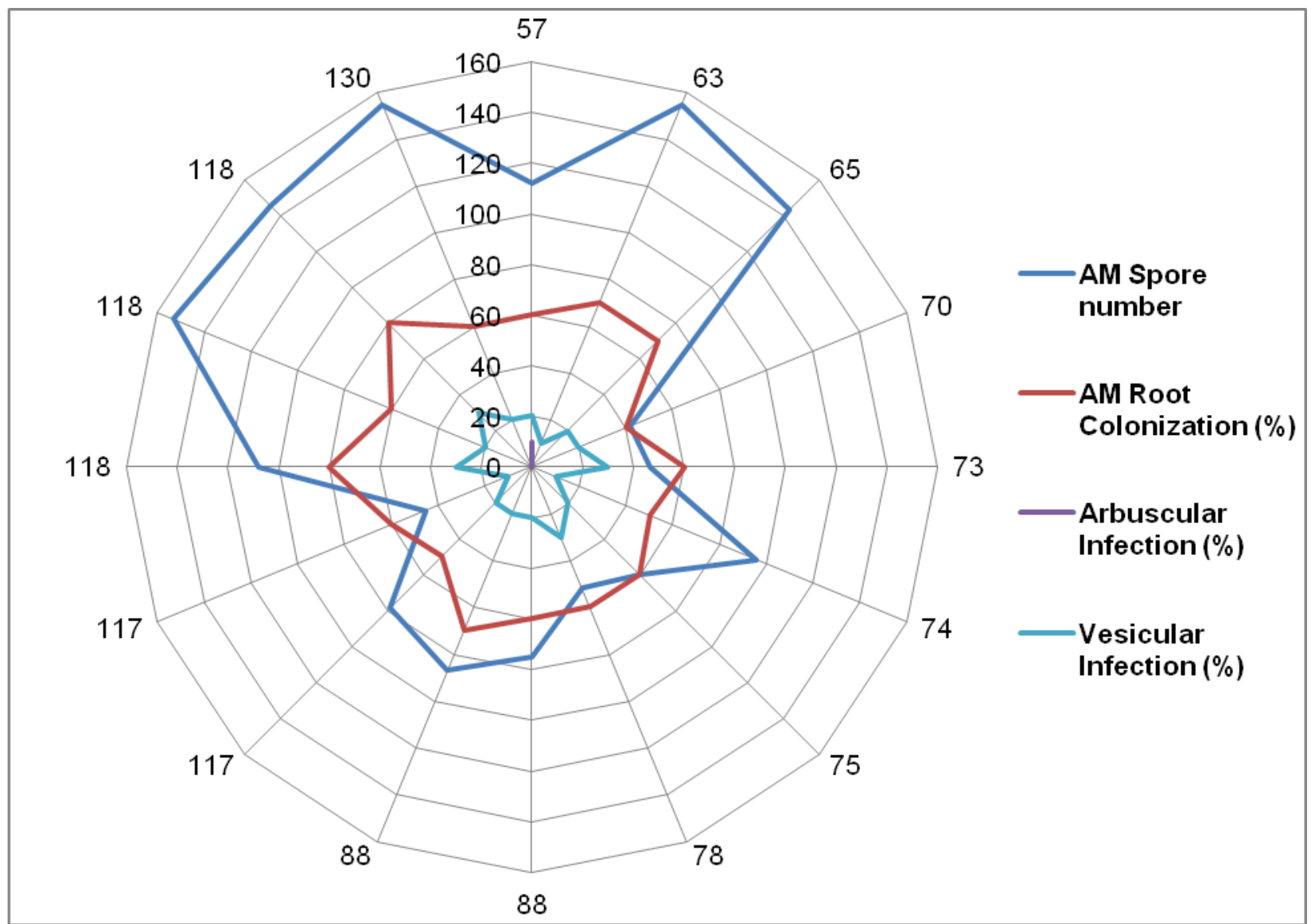

Fig. 6 - Elevation wise variation in endomycorrhizal quantification and root colonization (on an average data)

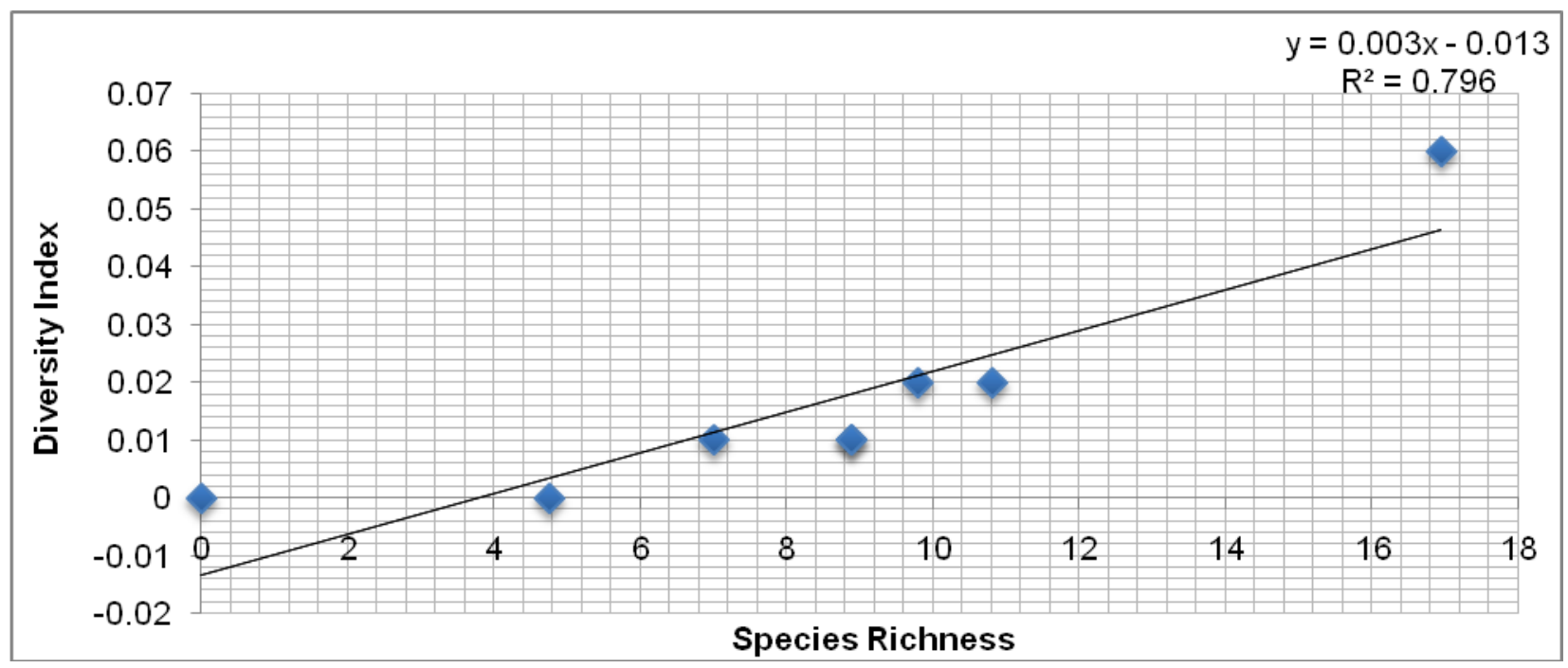

Fig. 7 - Scatter diagram between Species richness versus Diversity index of AM Fungi

\section{Discussion}

The role of rhizospheric fungi is extremely complex and is elemental to the soil ecosystem (Bridge \& Spooner 2001). Soil fungi play a vital role in nutrient cycling and plant health and development (Thorn 1997, Bridge \& Spooner 2001, Martin et al. 2001). Certain fungi cause a range of plant diseases (Jarosz \& Davelos 1995, Thorn 1997), while others, including AM fungi antagonize plant pathogens, provide nutrients to plants, and stimulate plant growth. Information on 
the knowledge of the diversity and structure of AM fungal communities dominant both in rhizoplane as well as rhizosphere soils help in enhanced understanding of their roles in soil ecosystem and in improving plant health. The AM symbiosis is a keystone to the productivity and diversity of natural plant ecosystems and seldom is found a situation where its' ecological presence AM isn't significant. Consequently, loss or perturbation of this relationship can lead to serious losses in terms of plant community degradation, silvi-/ phyto-health and/or productivity. Loss of AMF propagules will result in a decrease in the capacity of plants to take up nutrients, thereby lowering soil fertility. The stability of the ecosystem then becomes threatened (Jeffries et al. 2003). Again, soils containing AM flora compatible with an established plant ecosystem, may be subjected to a drastic change in plant community as a result of human intervention (e.g. deforestation, shifting agriculture, reforestation or re-vegetation) (Jeffries \& Barea 2001).Thus, determination of the soil fungal community composition along with physico-chemical properties of soil associated with rhizosphere of Abroma augusta is essential in order to evaluate above- and below-ground plant ecosystem health and functioning with a prospective to exploit myco-biota for future conservation strategies.

Arbuscular mycorrhizal fungi develop intensively inside roots and within the soil by forming an extensive extra-radical network and this help plants considerably in exploiting mineral nutrients and water from the soil. Phosphorus is the key element obtained by plants through the symbiosis and the evidence to support this is extensive (Smith \& Read 1997). In exchange, mycorrhizal plants provide the fungus with photosynthetic Carbon (C), which in turn is delivered to the soil via fungal hyphae. The extra radical hyphae of AMF therefore act as a direct conduit for host $\mathrm{C}$ into the soil and contribute directly to its $\mathrm{C}$ pools, bypassing the decomposition process. As a consequence of this, the amount and activity of other soil biota are stimulated; however, this seems to be a selective phenomenon, since it stimulates in particular the microbes having antagonistic activity against soil-borne pathogens (Linderman 2000). The reason for this phenomenon is unknown, but this observation clearly indicates that AMF could be useful biological tools for maintaining healthy soil systems.

The quality of soil depends not only on its physical or chemical properties, but also on the diversity and activity of its biota (Doran \& Linn 1994). The rhizosphere is also a battlefield where the complex rhizosphere community, both micro-flora and micro-fauna, interact with soil-borne pathogens and influence the outcome of pathogen infection. The growth or activity of soil borne pathogenic fungi, oomycetes, bacteria, and/ or nematodes can be inhibited by several beneficial rhizosphere microorganisms (Weller 1988, Raaijmakers et al. 1995, Raaijmakers 2001). The rhizosphere of most crops or plants can exert an influence on the soil microbial communities within the soil (Gregory 2006). Root exudates from different plants can stimulate the growth of unique bacterial and fungal populations in the vicinity of roots (Rovira 1965). Arbuscular Mycorrhizal fungi are essential components of soil biota; they can be found in nearly all ecological situations, both in natural ecosystems, particularly in those supporting plant communities with high species diversity, and also in normal cropping systems, especially if managed with sustainable practices (Gianinazzi \& Schüepp 1994). The impact of AMF on the reduction of soilborne diseases has mainly been evaluated in studies on soil fungal pathogens such as Phytophthora, Aphanomyces, Fusarium and Verticillium (Azcön-Aguilar \& Barea 1996, Raaijmakers et al. 2009) and nematodes causing, respectively, root rots and lesions and galls (Guillemin et al. 1993, Pinochet et al. 1996). Some studies have shown that mycorrhizal protection could also occur against Erwinia carotovora and Pseudomonas syringae (Garcia-Garrido \& Ocampo 1989). Arbuscular Mycorrhizal fungi are obligate symbionts and their life cycle depends on plant roots, and in return they decrease disease in the latter and reduce population levels of pathogenic microorganisms in the soil, especially where the supply of phosphorus $(\mathrm{P})$ is limiting (Linderman 1994). 
Table 5 Ecological indices of AM fungi in rhizosphere of Abroma augusta

\begin{tabular}{|c|c|c|c|c|c|c|}
\hline $\begin{array}{l}\text { Sl. } \\
\text { No. }\end{array}$ & $\begin{array}{c}\text { Name of } \\
\text { endomycorrhizal (AM) } \\
\text { fungal species }\end{array}$ & Density & $\begin{array}{l}\text { Region-wise } \\
\text { Frequency } \\
(\%)\end{array}$ & $\begin{array}{c}\text { Species-wise } \\
\text { Frequency } \\
(\%)\end{array}$ & Abundance & $\begin{array}{c}\text { Occurrence } \\
(\%)\end{array}$ \\
\hline 1 & Acaulospora laevis & 0.50 & 37.50 & 16.67 & 1.33 & 7.69 \\
\hline 2 & A. foveata & 0.75 & 50.00 & 25.00 & 1.5 & 11.54 \\
\hline 3 & A. mellea & 0.25 & 12.50 & 8.33 & 2 & 3.85 \\
\hline 4 & A. denticulata & 1.13 & 87.50 & 37.50 & 1.29 & 17.31 \\
\hline 5 & A. bireticulata & 0.13 & 12.50 & 4.17 & 1 & 1.92 \\
\hline 6 & A. scrobiculata & 0.25 & 25.00 & 8.33 & 1 & 3.85 \\
\hline 7 & A. sp. & 0.50 & 37.50 & 16.67 & 1.33 & 7.69 \\
\hline 8 & Gigaspora gigantea & 0.13 & 12.50 & 4.17 & 1 & 1.92 \\
\hline 9 & Gi. sp. & 0.25 & 25.00 & 8.33 & 1 & 3.85 \\
\hline 10 & Glomus albidum & 0.13 & 12.50 & 4.17 & 1 & 1.92 \\
\hline 11 & Gl. clavisporum & 0.50 & 50.00 & 16.67 & 1 & 7.69 \\
\hline 12 & Gl. geosporum & 0.88 & 37.50 & 29.17 & 2.33 & 13.46 \\
\hline 13 & Gl. convulutum & 0.13 & 12.50 & 4.17 & 1 & 1.92 \\
\hline 14 & Gl. macrocarpum & 0.50 & 25.00 & 16.67 & 2 & 7.69 \\
\hline 15 & Gl.mosseae & 0.25 & 25.00 & 8.33 & 1 & 3.85 \\
\hline 16 & Gl. multicaulis & 0.13 & 12.50 & 4.17 & 1 & 1.92 \\
\hline 17 & Gl. multisubstensum & 0.13 & 12.50 & 4.17 & 1 & 1.92 \\
\hline 18 & Gl. pallidum & 0.63 & 50.00 & 20.83 & 1.25 & 9.62 \\
\hline 19 & Gl.pansihalos & 0.13 & 12.50 & 4.17 & 1 & 1.92 \\
\hline 20 & Gl. sp. & 0.25 & 25.00 & 8.33 & 1 & 3.85 \\
\hline 21 & Gl. microcarpum & 0.13 & 12.50 & 4.17 & 1 & 1.92 \\
\hline 22 & Gl. segmentatum & 0.13 & 12.50 & 4.17 & 1 & 1.92 \\
\hline
\end{tabular}

The important role of the soil mycelium of mycorrhizal fungal mycelium in the formation of water-stable soil aggregates is well documented (Andrade et al. 1998, Bethlenfalvay et al. 1999, Miller \& Jastrow 2000). Indeed, AMF produce a very stable hydrophobic glycoprotein, glomalin, which is deposited on the outer hyphal walls of the extraradical mycelium and on adjacent soil particles, and which appears to act as a long-term soil binding agent (Wright \& Upadhyaya 1998, 1999). As a consequence, the extraradical hyphae, together with the fibrous roots, can form a "sticky-string bag that contributes to the entanglement and enmeshment of soil particles to form macroaggregates" (Miller \& Jastrow 2000), a basic building block of soil structure. This underlines once more that AMF are essential components of ecosystems and that their use could be crucial, not only for re-vegetation of spoiled lands, but more importantly for maintaining soil structure in agricultural soils. Many biotic and abiotic interactions around roots are probably mediated by AMF and, as suggested by Bethlenfalvay \& Lindermann (1992), "the role of AMF may be critical if agriculture is to return to the state where luxury levels of farm inputs of fertilisers, pesticides and or chemicals are decreased to levels that are still economic, yet do not pollute the environment or pose health risks to consumers or handlers". However, a successful shift in emphasis from chemicals to natural methods, such as crop rotation and the rational use of beneficial soil microorganisms, such as AMF, requires better knowledge on the dynamic relationships between agricultural practices and spatio-temporal interactions between cultivated crops, AMF and other soil biota. 
Table 6 Pearson's correlation analyses amongst various external environmental factors along with endomycorrhizal (AM) quantification, root colonization of collected samples and ecological indices of study sites harboring Abroma augusta

\begin{tabular}{lcccc}
\hline \multicolumn{1}{c}{$\begin{array}{c}\text { External Environmental } \\
\text { Factors }\end{array}$} & $\begin{array}{c}\text { Percent root } \\
\text { colonization }\end{array}$ & $\begin{array}{c}\text { AM spore } \\
\text { number } \\
\text { (/50 g of soil) }\end{array}$ & $\begin{array}{c}\text { Species } \\
\text { richness }\end{array}$ & Diversity Index \\
\hline Biotic Factor & -0.11 & $\mathbf{0 . 2 0}$ & -0.19 & -0.04 \\
$\begin{array}{l}\text { Height of plant } \\
\text { Edaphic Factor }\end{array}$ & $\mathbf{0 . 1 4}$ & $\mathbf{0 . 1 6}$ & -0.15 & $\mathbf{0 . 1 8}$ \\
Soil pH & -0.17 & -0.20 & -0.39 & -0.23 \\
Soil Electrical Conductivity & -0.01 & -0.25 & -0.12 & -0.33 \\
Soil Temperature & $\mathbf{0 . 2 3}$ & $\mathbf{0 . 0 6}$ & -0.27 & -0.43 \\
Soil Moisture Content (\%) & -0.14 & $\mathbf{0 . 2 1}$ & -0.06 & -0.02 \\
Available Soil Organic Carbon & & & & \\
(\%) & & -0.10 & -0.32 & -0.45 \\
Climatic Factor & & & & \\
Relative Humidity & $\mathbf{0 . 2 0}$ & $\mathbf{0 . 1 8}$ & $\mathbf{0 . 1 3}$ & -0.08 \\
Physiographic Factor & -0.04 & & & \\
Site Elevation & & &
\end{tabular}

Many chemical reactions that influence nutrient availability e.g. adsorption, precipitation are influenced by the soil chemical environment and soil $p \mathrm{H}$ in particular (Schoenholtza et al. 2000). Soil $p \mathrm{H}$ is simply a surrogate for this complex of potentially nutrient limiting processes, must be evaluated against the sensitivity of the target vegetation or crop and may in some instances not be the best measure of soil acidity and soil quality degradation (Aune \& Lal 1997). Powell \& Bagyaraj (1984) also concluded that $p \mathrm{H}$ can influence spore germination of AM fungal species and that AM spore germination occurs within a range that is acceptable for plant growth. Soil $p \mathrm{H}$ over a range of 4.8-8 significantly influence spore germination (Daniels \& Trappe 1980, Basumatary et al. 2015). Our present study, exhibited that $p \mathrm{H}$ levels between 5.69-8.4 promoted not only AM fungal density but also host plant height. On the other hand, Electrical Conductivity (EC) as a measure of ion concentration and the potentially negative effect of salinity on the osmotic potential i.e. water relations and nutrient imbalances ( $\mathrm{Na}$ dominance in sodic soils) is primarily used in agricultural soils. Its application to forest soils is usually limited to very specific circumstances (e.g. reclamation of mine soils) where highly concentrated soil solutions are known or suspected to inhibit forest growth and productivity (Burger et al. 1994). The present study divulged the fact that EC within the range of 57.6-125.1 $\mathrm{dSm}^{-1}$ promoted host plant height, while the range of 40.3-91.4 $\mathrm{dSm}^{-1}$ was facilitating AM spore populace. Soil temperature has a dominant influence on plant growth, both directly and indirectly (Willis \& Power 1975). Although the temperature range projected by the present study as characteristic of the plant's habitat is $20-34$ ${ }^{\circ} \mathrm{C}$; yet arbuscular infections were present only at lower (in this context) temperature $\left(20^{\circ} \mathrm{C}\right)$. The Soil organic matter (SOM) or soil organic carbon (SOC) is commonly recognized as one of the key chemical parameters of soil quality, yet quantitative assessment of its contribution to soil quality is often lacking. Soil organic carbon is a critical pool in the carbon cycle and a repository of nutrients and through its influence on many fundamental biological and chemical processes; it plays a pivotal role in nutrient release and availability (Johnson 1985, Henderson et al. 1990, Henderson 1995, Nambiar 1997). Our present observations reveal that an SOC range of 0.3-1.29 $\%$ enhances plant height as well as AM spore density. Most of the rhizospheric study locations were characterized by presence of minerals, viz.- goethite and lepidocrocite $(\mathrm{FeOOH})$; although 


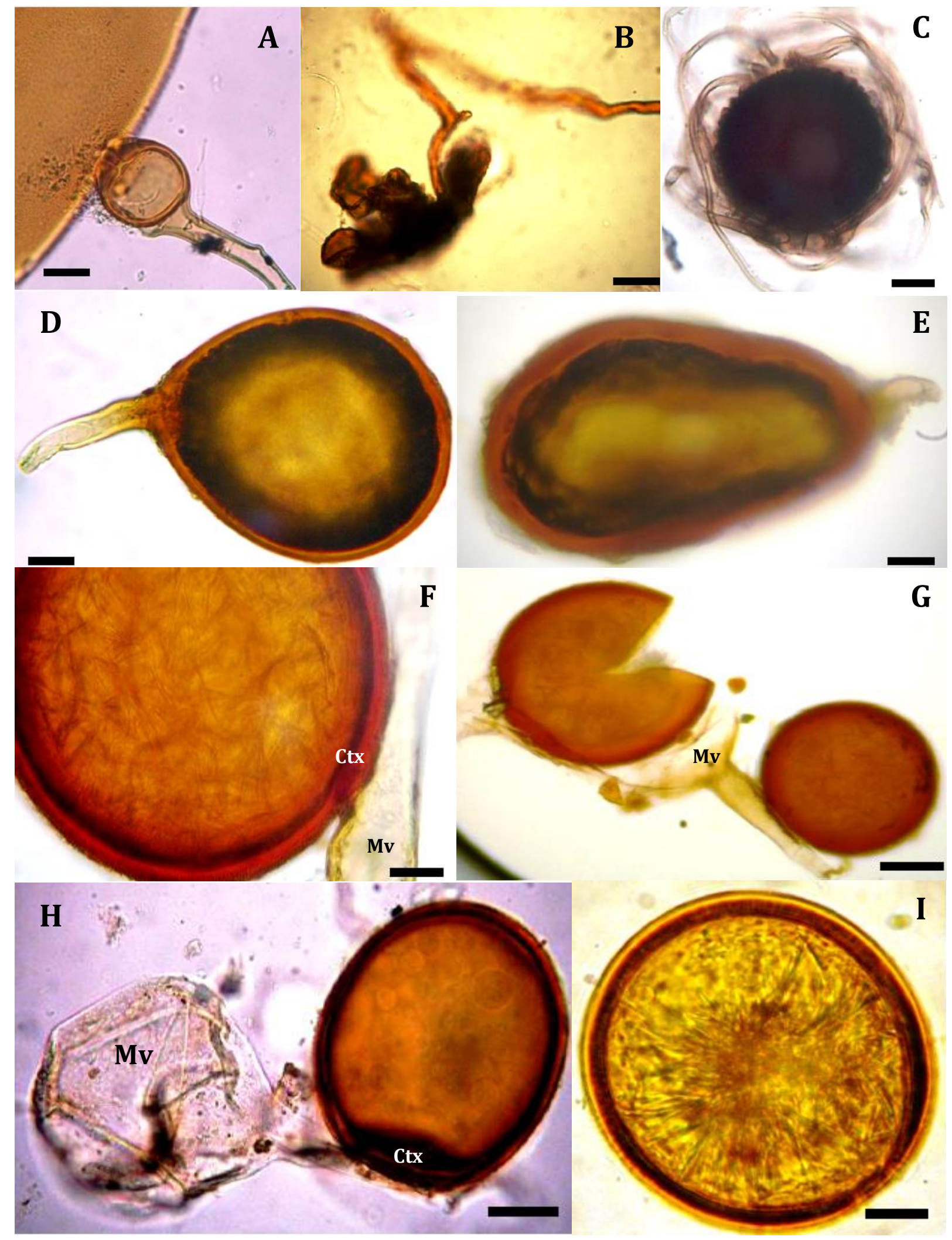

Fig 8 - A-I - A: Gigaspora gregaria (showing bulbous suspensor attachment with spore only). B, C: Auxiliary cells of Gigaspora species. D: Glomus mosseae. E: Glomus clavisporum. F-G: Acaulospora denticulata. H: Acaulospra laevis with mother vesicle (Mv) and cicatrix (Ctx). I: Acaulospora mellea (All images at 400X and Bars $=20 \mu \mathrm{m}$ ). 
two roadside habitats of study locations BRHL/MDP/2 (Borholla) and KJRG/NMGP/12 (Kaziranga) were characterized by the presence of mineral quartz $\left(\mathrm{SiO}_{2}\right)$ as per Munsell soil classification colour code (http://www.nrcs.usda.gov/wps/portal/nrcs/detail/soils/edu/?cid=nrcs 142 p2 _ 054286 ).

In this study, the percentage root colonization was observed to decrease gradually with increase in host plant height; study site elevation along with electrical conductivity, temperature and available organic carbon (\%) of soil. On the other hand, with increase in relative humidity apart from $\mathrm{pH}$ and moisture content (\%) pertaining to soil; the colonization frequency were found to gradually increase. On the other hand, the AM spore numbers per $50 \mathrm{~g}$ of soil was observed to decrease gradually with increase in relative humidity as well as temperature and electrical conductivity related to the rhizosphere. Again, with increase in plant height, site elevation along with $p \mathrm{H}$, moisture content (\%) and available organic carbon (\%) of soil; the AM spore numbers were found to gradually increase. In the context of ecological indices relating AM fungi; Species richness was augmented by site elevation while soil $p \mathrm{H}$ amplified Diversity index.

Previous researches have demonstrated that low soil/ root temperature resulted in reduction of percent AM colonization of host plant's root (Sam et al. 1983, Smith \& Roncadori 1986, Baon et al. 1994). Yet, it must be borne in mind that these studies are the results of studies conducted in greenhouses. Moreover, AM morpho-species, depending on the occurrence site may express varying degrees of temperature tolerance (Grey 1991). On the other hand, soil $p \mathrm{H}$ and available organic carbon (\%) of soil had an adverse effect on percent mycorrhizal root colonization; which in contradiction to earlier researches. In some these factors were observed influencing the intraradical development of these fungi (Carrenho et al. 2007); while in some others no influence were observed (Khakpour \& Khara 2012). However, the deleterious role of soil electrical conductivity on AM root colonization (\%) and AM spore quantification was in concordance with earlier researches (Mohammad et al. 2003, Khakpour \& Khara 2012, Basumatary et al. 2014).

Mycorrhizal associations encompass a broad range of habitats ranging from aquatic to high altitudes; almost in every terrestrial ecosystem. They have even been reported to occur symbiotically with roots of cultivated and wild plants growing in disturbed and un-disturbed saline soils, including marshlands, river bank, roadsides, and even on the edges of salt slick (Aliasgharzadeh et al. 2001, Hildebrandt et al. 2001, García \& Mendoza 2007). This accounts for the maximum AM spore density in rhizosphere as well as fairly large root colonization in roots of plants collected from riverine areas. The disturbance of topsoil is reported to decrease the colonization potential of the extrametrical AM fungal hyphal network (Jasper et al. 1989). This might account to the fact that fallow lands, where there is no scope of anthropogenic interference on the soil layer, accounts for the presence of arbuscular infection, amongst the various study habitats. The foot hills, characterized by the high as well as low level of certain edaphic environmental variables, are observed to exhibit maximum AM spore density as well as percent vesicular colonization.

The ecology of microorganisms, however, cannot be considered solely in terms of their relationships with the abiotic environment, because their success in a given situation reflects their ability to co-exist with other microorganisms (Jha et al. 1992). However, the link between rhizospheric fungal biota and abiotic soil properties can be exclusively advocated for a broader utilization as an ecological indicator for any plant species. Therefore, the present study is an attempt to determine the association ecology of an endangered plant species like Abroma augusta under threat due to anthropogenic pressure in the Brahmaputra valley of Assam, India.The diversity of AMF has significant ecological consequences because individual species or isolates vary in their potential to promote plant growth and adaptation to biotic and abiotic factors. Thus, the composition and dynamics of populations of AMF have a marked impact on the structure and diversity of the associated plant communities, both in natural and agricultural ecosystems (Grime et al. 1987, Gange et al. 1990, van der Heijden et al. 1999). An important prerequisite to the analysis of populations of AMF in ecological studies is the correct identification of individual isolates. The association between rhizospheric fungal biota including endomycorrhizae and abiotic 
soil properties can be exclusively advocated for a broader utilization as an ecological indicator for the conservation of target plant species. Keeping in view the association ecology of nonmycorrhizal as well as Arbuscular mycorrhizal fungal strains/ isolates from the host plant and advantageous role played by these microbes and other edaphic and environmental factors as examined, the results were harnessed and utilized in conserving the plant in question and the establishment of a conservation plot in the institute campus.

\section{Acknowledgements}

The senior author, VP is thankful to Indian Council of Forestry Research and Education, Dehradun for financial assistance in the project no. RFRI-42/2010-11/SFM in order to carry out the survey. Authors VP and AJS are also thankful to Mr. Debajyoti Bora, Assistant Professor, CKB Commerce College, Jorhat and Miss Rituparna Dutta, JRF for their laboratory assistance in performing the experiments.

\section{References}

Adholeya A, Gaur A.1994 - Estimation of VAM fungal spores in soil. Mycorrhiza News 61, 1011.

Al-Bari MAA, Sayeed MA, Rahman MS. 2006 - Characterization and antimicrobial activities of a phenolic acid derivative produced by Streptomyces bangladeshiensis, a novel species collected in Bangladesh. Journal of Research in Medical Science 1, 77-81.

Ali Hussain HEM. 2002 - Hypoglycemic, hypolipidemic and antioxidant properties of combination of Curcumin from Curcuma longa, Linn, and partially purified product from Abroma augusta Linn. in streptozotocin induced diabetes. Indian Journal of Clinical Biochemistry 17(2), 33-43.

Aliasgharzadeh N, Rastin NS, Towfighi H, Alizadeh A. 2001 - Occurrence of arbuscular mycorrhizal fungi in saline soils of the Tabriz plain of Iran in relation to some physical and chemical properties of soil. Mycorrhiza 11, 119-122.

Allen SE. 1974 - Chemical Analysis of Ecological Materials. Wiley \& Sons, New York.

Andrade G, Mihara KL, Linderman RG, Bethlenfalvay GJ. 1998 - Soil aggregation status and rhizobacteria in the mycorrhizosphere. Plant Soil 202, 89-96.

Anonymous. 2006 - The Wealth of India. NISCAIR Press Publisher, New Delhi.

Aune JB, Lal R. 1997 - The tropical soil productivity calculator: A model for assessing effects of soil management on productivity. In: Lal R, Stewart BA. (Eds.) Soil Management Experimental Basis for Sustainability and Environmental Quality. Adv. Soil Sci. Lewis Publishers, London, UK.

Azcön-Aguilar C, Barea JM. 1996 - Arbuscular mycorrhizas and biological control of soil-borne plant pathogens: an overview of the mechanisms involved. Mycorrhiza 6, 457-464.

Baon JB, Smith SE, Alston AM. 1994 - Phosphorus uptake and growth of barely as affected by soil temperature and mycorrhizal infection. Journal of Plant Nutrition 17(2-3), 479-492.

Barea JM, Azcón R, Azcón-Aguilar C. 1993 - Mycorrhiza and crops. Advances on Plant Pathology 9, 167-189.

Basumatary N, Parkash V, Tamuli AK, Saikia AJ, Teron R. 2014 - Arbuscular mycorrhizal inoculation affects growth and rhizospheric nutrient availability in Hevea brasiliensis (Willd. ex A. Juss.) Mull. Arg. clones, International Journal of Current Biotechnology 2(7), $14-21$.

Basumatary N, Parkash V, Tamuli AK, Saikia AJ, Teron R. 2015 - Distribution and diversity of arbuscular mycorrhizal fungi along with soil nutrient availability decline with plantation age of Hevea brasiliensis (Willd. ex A. Juss.) Müll. Arg. The Journal of Biodiversity 115, 401-412. 
Bethlenfalvay GJ, Cantrell IC, Mihara KL, Schreiner RP. 1999 - Relationships between soil aggregation and mycorrhizae as influenced by soil biota and nitrogen nutrition. Biology and Fertility of Soils 28, 356-363.

Bethlenfalvay GJ, Linderman RG. 1992 - Mycorrhizae in sustainable agriculture. (ASA Special publication no 54) Madison, Wis.

Bisht R, Bhattacharya S, Jaliwala YA. 2014 - Evaluating the use of root extract of Abroma augusta as alpha glucosidase inhibitor for Type-II diabetes. Annals of Plant Sciences 3(4), 686-691.

Blaszkowski, J. 2003 - Arbuscular mycorrhizal fungi (Glomeromycota), Endogone and Complexipes species deposited in the Department of Plant Pathology, University of Agriculture in Szczecin, Poland. http://zor.zut.edu.pl/Glomeromycota/index.html (Accessed on April - August, 2014).

Bridge P, Spooner BM. 2001 - Soil fungi: diversity and detection. Plant and Soil 232, 147-154.

Brundrett M. 1991 - Mycorrhizas in natural ecosystems. Advances in Ecological Research 21, 171-313.

Burger JA, Johnson JE, Andrews JA, Torbert JL. 1994 - Measuring mine soil productivity for forests. In: International Land Reclamation and Mine Drainage Conference on Reclamation and Revegetation, Vol. 3. USDOI Bureau of Mines, Special Publication SP 06C-94.

Carrenho R, Trufem SFB, Bononi VLR, Silva ES. 2007 - The effect of different soil properties on arbuscular mycorrhizal colonization of peanuts, sorghum and maize. Acta Botanica Brasilica 21(3), 723-730.

Curtis JT, McIntosh RP. 1950 - The interrelations of certain analytic and synthetic phytosociological characters. Ecology 31, 434-455.

Daniels BA, Trappe, J.M. 1980 - Factors affecting spore germination of the vesicular-arbuscular mycorrhizal fungus, Glomus epigaeus. Mycologia 72, 457-471.

Das H. 2014 - Assam (state, India). Encyclopædia Britannica. http://www.brittannica.com/EB checked/topic/39101/Assam (Accessed on April, 2014).

Das S, Datta R, Nandy S. 2012 - Phytochemical screening and evaluation of anti-inflammatory activity of methanolic extract of Abroma augusta Linn. Asian Pacific Journal of Tropical Disease 2(S1), 114-117.

Doran JW, Linn DM. 1994 - Microbial ecology of conservation management systems. In: Hatfield JL, Stewart BA. (eds.) Soil biology: effects on soil quality. (Advances in soil science) Lewis, Boca Raton, Fla.

Eshrat MH. 2003 - Effect of Coccinia indica (L.) and Abroma augusta (L.) on glycemia, lipid profile and on indicators of end organ damage in streptozotocin induced diabetic rats. Indian Journal of Clinical Biochemistry 18(2), $54-63$.

Gange AC, Brown VK, Farmer LM. 1990 - A test of mycorrhizal benefit in an early successional plant community. New Phytologist 115, 85-91.

García IV, Mendoza RE. 2007 - Arbuscular mycorrhizal fungi and plant symbiosis in a salinesodic soil. Mycorrhiza 17(3), 167-174.

Garcia-Garrido JM, Ocampo JA. 1989 - Effect of VA mycorrhizal infection of tomato on damage caused by Pseudomonas syringae. Soil Biology \& Biochemistry 21, 65-167.

Gerdemann JW, Nicolson YH. 1963 - Spores of mycorrhizae Endogone species extracted from soil by wet sieving and decanting. Transactions of British Mycological Society 46, 235244.

Gianinazzi S, Schüepp H. 1994 - Impact of arbuscular mycorrhizas on sustainable agriculture and natural ecosystems. ALS, Birkh_user, Basel, Switzerland.

Gregory PJ. 2006 - Roots, rhizosphere and soil: The route to a better understanding of soil science? European Journal of Soil Science 57, 2-12.

Grey WE. 1991 - Influence of temperature on colonization of spring barleys by vesicular arbuscular mycorrhizal fungi. Plant and Soil 137(2), 181-190. 
Grime JP, Mackey JM, Hillier SM, Read DJ. 1987 - Floristic diversity in a model system using experimental microcosms. Nature 328, 420-422.

Guillemin JP, Abdel-Fattah GM, Trouvelot A, Gianinazzi S, Gianinazzi-Pearson V. 1993 Interactions between soil-applied fungicides, endomycorrhiza fungal activity and plant growth. Soil Science (Trends in Agricultural Science) 1, 161-172.

Gupta B, Nayak S, and Solanki S. 2011 - Abroma augusta Linn. : A review. Der Pharmacia Sinica 2(4), 253-26.

Henderson GS, Hammer RD, Grigal DF. 1990 - Can measurable soil properties be integrated into a framework for characterizing forest productivity? In: Gessel, S.P., Lacate, D.S., Weetman GF, Powers RF. (Eds.) Proceedings of the 7th North American Forest Soils Conference on Sustained Productivity of Forest Soils. University of British Columbia, Faculty of Forestry, Vancouver, BC.

Henderson GS. 1995 - Soil organic matter: a link between forest management and productivity. In: McFee WW, Kelly JM. (Eds.) Proceedings of the 8th North American Forest Soils Conference on Carbon Forms and Functions in Forest Soils. Soil Science Society of America., Madison, WI.

Hildebrandt U, Janetta K, Quziad F, Renne B, Nawrath K, Bothe H. 2001 - Arbuscular mycorrhizal colonisation of halophytes in central European salt marshes. Mycorrhiza 10(4), 175-183.

Isobe K, Aizawa E, Iguchi Y, Ishii R. 2007 - Distribution of arbuscular mycorrhizal fungi in upland field soils of Japan. 1. Relationship between spore density and the soil environmental factor. Plant Production Science 10(1), 122-128, Doi:10.1626/pps.10.122

Jarosz AM, Davelos AL. 1995 - Effects of disease in wild plant populations and the evolution of pathogen aggressiveness. New Phytologist 129, 371-387.

Jasper DJ, Abbott LK, Robson AD. 1989 - The loss of VA mycorrhizal infectivity during bauxite mining may limit the growth of Acacia pulchella R. Br. Australian Journal of Botany 37, 33-42.

Jeffries P, Barea JM. 2001 - Arbuscular mycorrhiza: a key component of sustainable plant-soil ecosystems. In: Hock B. (ed.) The Mycota. Vol IX: fungal associations, Springer, Berlin Heidelberg New York.

Jeffries P, Gianinazzi S, Perotto S, Turnau K, Barea JM. 2003 - The contribution of arbuscular mycorrhizal fungi in sustainable maintenance of plant health and soil fertility. Biology and Fertility of Soils 37, 1-16.

Jha DK, Sharma GD, Mishra RR. 1992 - Ecology of soil microflora and mycorrhizal symbionts. Biology and Fertility of Soils 12, 272-278.

Johnson DW. 1985 - Forest nutrient cycles as affected by climate, species composition, stand age and intensive harvesting. IEA/ ENFOR Report No. 1, p. 15.

Khakpour O, Khara J. 2012 - Spore density and root colonization by arbuscular mycorrhizal fungi in some species in the northwest of Iran. International Research Journal of Applied and Basic Sciences 3(5), 977-982.

Kirtikar KR, Basu BD. 1918 - Indian Medicinal Plants. Sudhindra Nath Basu, Bahadur Ganj, Allahabad, India.

Kivlin SN, Hawkes CV, Treseder KK. 2011 - Global diversity and distribution of arbuscular mycorrhizal fungi. Soil Biology \& Biochemistry 43(11), 2294-2303, Doi: 10.1016/j.soilbio.2011.07.012

Linderman RG. 1994 - Role of VAM fungi in biocontrol. In: Pfleger FL, Linderman RG (eds) Mycorrhizae and plant health. APS Press, St Paul, Minn.

Linderman RG. 2000 - Effects of mycorrhizas on plant tolerance to diseases. In: Kapulnik Y, Douds DD Jr. (eds.) Arbuscular mycorrhizas: physiology and function. Kluwer Academic, Dordrecht, The Netherlands. 
Martin FM, Perotto S, Bonfante P. 2001 - Mycorrhizal fungi. In: Pinton R, Varanini Z, Nannipieri P. (Eds.) The Rhizosphere - a fungal community at the interphase between soil and roots. New York, Marcel Dekker.

Miller RI, Bratton SP, White PS.1987 - A regional strategy for reserve design and placement based on an analysis of rare and endangered species' distribution patterns. Biological Conservation 39, 255-268.

Miller RM, Jastrow JD. 2000 - Mycorrhizal fungi influence soil structure. In: Kapulnik Y, Douds DD (eds.) Arbuscular mycorrhizas: physiology and function. Kluwer Academic, Dordrecht, The Netherlands.

Mir SH, Darzi MM, Mir MS. 2013 - Efficacy of Abroma augusta on biochemical and histomorphological features of alloxan-induced diabetic rabbits. Iranian Journal of Pathology 8(3), 153-158.

Mohammad MJ, Hamadt SR, Malkawit HI. 2003 - Population of arbuscular mycorrhizal fungi in semi-arid environment of Jordan as influenced by biotic and abiotic factors. Journal of Arid Environments 53, 409-417, Doi:10. 1006/jare.2002.1046.

Morton J. 2014 - International Culture Collection of (Vesicular) Arbuscular Mycorrhizal Fungi. http://invam.caf.wvu.edu (Accessed on April - August, 2014).

Morton JB, Benny GL. 1990 - Revised classification of arbuscular mycorrhizal fungi (zygomycetes), a new order Glomales, two new suborders Glomineae and Gigasporinae and two new families Acaulosporaceae and Gigasporaceae with an emendation of Glomaceae. Mycotaxon 37, 471-479.

Morton JB, Redecker D. 2001 - Two new families of Glomales, Archaeosporaceae and Paraglomaceae, with two new genera Archaeospora and Paraglomus, based on concordant molecular and morphological characters. Mycologia 93,181-195.

Mukerji KG. 1996 - Taxonomy of endomycorrhizal fungi. In: Mukerji KG, Mathur B, Chamola BP, Chitralekha P. (Eds.) Advances in Botany. APH Corporation, New Delhi, India.

Munsell 2000 - Munsell Soil Color Charts. Macbeth Division of Kollmorgen Corporation, New Windsor, NY, USA.

Nahar L, Ripa FA, Zulfiker AHM, Rokonuzzaman M, Haque M , Islam KMS. 2010 Comparative study of anti-diabetic effect of Abroma augusta and Syzygium cumuni on alloxan-induced diabetic rat, Agriculture and Biology Journal of North America 1(6), 1268-1272.

Nambiar EKS.1997 - Sustained productivity of forests as a continuing challenge to soil science. Soil Science Society of America Journal 60, 1629-1642.

Nannipieri P, Ascher J, Ceccherini MT, Landi L, Piandramellara G, Renella G. 2003 - Microbial diversity and soil functions, European Journal of Soil Science 54, 655-670, Doi: 10.1046/j.1365-2389.2003.00556.x.

Parkash V, Saikia AJ, Bora D. 2014 - Locational variability of physico-chemical properties of rhizospheric soil and myco-biota associated with Abroma augusta L. Advances in Bioresearch 5(3), 156-165.

Parkash V, Saikia AJ, Dutta R, Borah D. 2013 - Wild medicinal plants of Umtasoar Range under Nonghkyllem Reserve Forest, Nongpoh, Meghalaya, India and their traditional usage by Khasi tribe -I. Journal of Ethnobiology and Traditional Medicine 118, 228-237.

Parkash V. 2012 - Utilization of Vesicular Arbuscular mycorrhizal diversity for the quality stock production of some useful forest plant/s species of Nongkhyllem Reserve forest, Nongpoh, Meghalaya, India. Project Completion Report (RFRI-12/2008-09/SFM). Rain Forest Research Institute, Jorhat, Assam, India.

Patel DK, Dhanabal SP. 2013 - Determination of bioanalytical parameters for the standardization of Abroma augusta. Journal of Acute Diseases 2(4), 292-295.

Paudel S, Sah JP. 2003 - Physiochemical characteristics of soil in tropical sal (Shorea robusta Gaertn.) forests in eastern Nepal. Himalayan Journal of Science 1(2), 107-110. 
Phillips JM, Hayman D S. 1970 - Improved produces for clearing roots and staining parasitic and VAM fungi for rapid assessment of infection. Transactions of British Mycological Society $55,158-161$.

Pinochet J, Calvet C, Camprubi A, Fernandez C. 1996 - Interactions between migratory endoparasitic nematodes and arbuscular mycorrhizal fungi in perennial crops: a review. Plant and Soil 185, 183-190.

Powell CL, Bagyaraj DJ. 1984 - VA mycorrhizal. CRC Press, Boca Raton, Florida.

Raaijmakers JM, Leeman M, Van Oorschot MMP, Van der Sluis I, Schippers B, Bakker PAHM. 1995 - Dose-response relationships in biological control of fusarium wilt of radish by Pseudomonas spp. Phytopathology 85, 1075-1081.

Raaijmakers JM, Paulitz TC, Steinberg C, Alabouvette C, Moënne-Loccoz Y. 2009 - The rhizosphere: a playground and battlefield for soilborne pathogens and beneficial microorganisms. Plant and Soil 321, 341-36, Doi:10.1007/s11104-008-9568-6.

Raaijmakers JM. 2001 - Rhizosphere and rhizosphere competence. (Eds. Maloy OC, Murray TD) Encyclopedia of Plant Pathology. Wiley, USA.

Rahmatullah M, Sadeak SMI, Bachar SC, Hossain MT, Abdullahal-Mamun, Montaha, et al. 2010 - Brine Shrimp Toxicity Study of different Bangladeshi Medicinal Plants. Advances in Natural and Applied Sciences 4(2), 163-73.

Rovira AD. 1965 - Interactions between plant roots and soil micro-organisms. Annual Review of Microbiology 18, 241-266.

Saikia AJ, Parkash V. 2014 - Arbuscular Mycorrhizal Status of Some Alien Forest Invasive Species Invading Hoollongapar Gibbon Sanctuary, Jorhat, Assam, India. Mycorrhiza News 26(1), 2-8.

Saikot FK, Khan A, Hasan MF. 2012 - Antimicrobial and cytotoxic activities of Abroma augusta Linn. leaves extract. Asian Pacific Journal of Tropical Biomedicine 2, S1418-S1422.

Sam BI, Robson AD, Abbott LK. 1983 - Phosphorus, soluble carbohydrates, and endomycorrhizal infection. Soil Biology \& Biochemistry 15(5), 593-597.

Schenck NC, Perez Y. 1990 - Manual for the identification of VA mycorrhizal VAM fungi. Univ. of Florida, Synergistic Pub., Florida, USA.

Schoenholtza SH, Miegroetb HV, Burgerc JA. 2000 - A review of chemical and physical properties as indicators of forest soil quality: challenges and opportunities. Forest Ecology and Management 138, 335-356.

Schüßler A, Schwarzott D, Walker C. 2001 - A new fungal phylum, the Glomeromycota: Phylogeny and evolution. Mycological Research 105, 1413-1421.

Sharma S, Parkash V, Aggarwal A. 2008 - Glomales I: A monograph of Glomus spp. in rhizosphere of sunflower (Glomaceae) of Haryana, India. Helia 31(49), 13-18.

Sharma S, Parkash V, Aggarwal A. 2009 - A monograph of Acaulospora spp. (VAM fungi) in rhizosphere of sunflower in Haryana, India. Helia 32(50), 69-76.

Smith GS, Roncadori RW. 1986 - Response of three vesicular-arbuscular mycorrhizal fungi at four soil temperatures and their effects on cotton growth. New Phytologist 104, 89-93

Smith SE, Read DJ. 1997 - Mycorrhizal symbiosis. Academic Press, London.

Stotzky G. 1997 - Soil as an environment for microbial life. In: van Elsas JD, Trevors JT, Wellington EMH. (eds.) Modern Soil Microbiology. Marcel Dekker, New York.

Tanwar A, Aggarwal A, Parkash V. 2014 - Effect of bioinoculants and superphosphate fertilizer on the growth and yield of broccoli (Brassica oleracea L. var. italica Plenck). New Zealand Journal of Crop and Horticultural Science, Doi: 10.1080/01140671.2014.924537.

Thorn G. 1997 - The fungi in soil. In: van Elsas JD, Trevors JT, Wellington EMH. (Eds.) Modern Soil Microbiology. New York, Marcel Dekker.

Trappe JM. 1982 - Synoptic key to the genera and species of zygomycetous mycorrhizal fungi. Phytophathology 72, 1107-1108. 
Treseder KK. 2004 - A meta-analysis of mycorrhizal responses to nitrogen, phosphorus and atmospheric CO2 in field studies. New Phytologist 164(2), 347-355, Doi: 10.1111/j.14698137.2004.01159.x.

van der Heijden MGA, Klironomos JN, Ursic M, Moutoglis P, Streitwolf-Engel R, Boller T, Wiemken A, Sanders JR. 1999 - Mycorrhizal fungal diversity determines plant biodiversity, ecosystem variability and productivity. Nature 396, 69-72.

Walker C. 1992 - Systematics and taxonomy of arbuscular endomycorrhizal fungi Glomales -A possible way forward. Agronomie 12, 887-897.

Walkley A, Black IA. 1934 - An examination of the Degtjareff method for determining organic carbon in soils: Effect of variations in digestion conditions and of inorganic soil constituents. Soil Science 63, 251-263.

Waltert B, Wiemken V, Rusterholz H., Boller T, Baur B. 2002 - Disturbance of forest by trampling: effects on mycorrhizal roots of seedlings and mature trees of Fagus sylvatica. Plant and Soil 243(2), 143-154, Doi: 10.1023/A:1019983625473

Weller DM. 1988 - Biological control of soilborne pathogens in the rhizosphere with bacteria. Annual Review of Phytopathology 26, 379-407.

Willis WO, Power JF. 1975 - Soil temperature and plant growth in the northern Great Plains. http://www.nal.usda.gov/ (Accessed on April, 2014).

Wright SF, Upadhyaya A. 1998 - A survey of soils for aggregate stability and glomalin, a glycoprotein produced by hyphae of arbuscular mycorrhizal fungi. Plant and Soil 198, 97107.

Wright SF, Upadhyaya A. 1999 - Quantification of arbuscular mycorrhizal fungi activity by the glomalin concentration on hyphal traps. Mycorrhiza 8, 283-285. 